\title{
Liquid Metal Embrittlement of Galvanized TRIP Steels in Resistance Spot Welding
}

\author{
Wook-Sang Jeon ${ }^{1}$, Ashutosh Sharma ${ }^{2}$ and Jae Pil Jung ${ }^{1, *}$ \\ 1 Department of Materials Science and Engineering, University of Seoul, 163 Seoulsiripdae-ro, \\ Dongdaemun-gu, Seoul 02504, Korea; dnrtkd12@uos.ac.kr \\ 2 Department of Energy Systems Research and Department of Materials Science and Engineering, \\ Ajou University, Suwon 16499, Korea; ashu@ajou.ac.kr \\ * Correspondence: jpjung@uos.ac.kr; Tel.: +82-2-6490-2408; Fax: +82-2-6490-2404
}

Received: 17 May 2020; Accepted: 10 June 2020; Published: 13 June 2020

check for updates

\begin{abstract}
Liquid metal embrittlement (LME) in Zn-coated steels is a serious issue in automotive design. The risk of rising LME surface cracks in resistance spot welding (RSW) of Zn-coated high strength steels has triggered significant research activities across the globe. This paper presents a state-of-the-art review of the various phenomena and issues related to LME during RSW. Various aspects of LME surface cracks have been described in this review, focusing on the macro- and microscopic features of LME, spot weld cracks, the sensitivity of the LME cracks towards surface locations, welding conditions, and susceptibility to high strength and galvanized steels. We also focus on the effects of various processing factors, such as temperature, stress, microstructure, and the nature of the galvanized layer, related to studies with actual spot welds LME cracks. Finally, we summarize the possible mechanisms of embrittlement and the remedies for minimizing LME cracks, with suitable guidelines to suppress surface cracks during RSW.
\end{abstract}

Keywords: steel; zinc; galvanization; spot welding; embrittlement; liquid

\section{Introduction}

\subsection{High Strength Steels: Trends and Definitions}

There are several types in advanced high strength steels (AHSSs), such as dual-phase (DP), transformation-induced plasticity (TRIP), twinning-induced plasticity (TWIP), complex phase (CP), martensitic (MART or MS), interstitials free (IF) steels, and so on [1]. AHSSs show good mechanical properties, are lightweight and a reasonable cost. AHSSs have unique microstructures, such as a combination of retained austenite, bainite, and/or ferrite multiphases, that are transformed or twinned during elongation. A brief classification of AHSSs steels can be summarized in Figure 1.

Generally, steels with yield strength higher than $550 \mathrm{MPa}$ are classified as AHSSs [2,3]. Steel is an important raw material for various industries. According to the World Steel Association report, the crude steel consumption across the globe (64 countries) in April 2020 was 137.1 million metric tons, with China being the top steel producer [4]. The global AHSSs market share was $\$ 13,147$ million in 2016. It is expected to reach $\$ 29,151$ million by 2023 , at a growth rate of $12.2 \%$ [5]. In this review, we will only discuss the important steels used in automotive structures. 


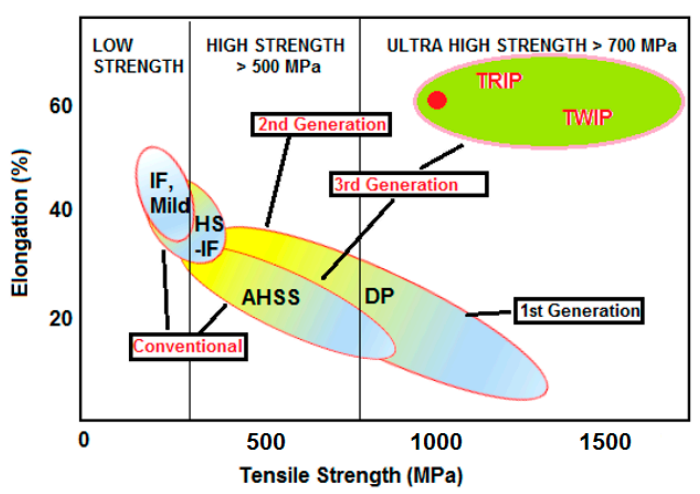

Figure 1. An overview of important advanced high strength steels (AHSSs).

\subsubsection{Dual-Phase Steel}

DP steels are commonly used steels in auto parts and they are composed of a soft ferrite and hard martensite structure in an island form [6,7]. The ductility-strength tradeoff generally depends upon the volume fraction of hard martensite. Mostly, DP steels are processed by a continuous cooling or annealing approach from the austenite phase to transform them into ferrite and martensite $[8,9]$.

A small number of other phases (bainite and retained austenite) can also be found. Recently, as reported by Srivastava et al., the annealing process can be well-controlled to achieve a Giga Pascal level steel by forming a core-shell structured network of ferrite and martensite in DP steel [10].

\subsubsection{Complex Phase Steels}

Various complex phase steels are available which can achieve higher ultimate tensile strengths. They are composed of martensite, retained austenite, and pearlite within the ferrite/bainite matrix. Some additive elements ( $\mathrm{Ti}$ or $\mathrm{Nb}$ ) are added to achieve extreme grain refinement or precipitation-hardening mechanisms. In contrast to DP steels, $\mathrm{CP}$ steels have higher yield strengths and are known for their high damping and residual deformation capacity, with good hole expansion ability $[10,11]$.

\subsubsection{TRIP Steel}

The main issue in the vehicle industry is to join the light, formable steel to the vehicle body. This is related to fuel efficiency and several environmental regulations, including the reduction of $\mathrm{CO}_{2}$ emission [12]. Therefore, the requirement for AHSSs is growing. TRIP steel is a material that has been receiving a lot of attention recently. The microstructure of TRIP steels, in general, contains retained austenite embedded in a primary ferrite matrix. Besides, a minimum of $5 \mathrm{vol} \%$ of retained austenite, martensite and bainite are present in varying amounts. The presence of high Si and C in TRIP steels also increases in retained austenite in the final microstructure.

TRIP steels contain retained austenite, usually stable at high temperature, to transform into martensite if tensile stress is applied to steel. These phenomena ensure that TRIP steels have more than a $1000 \mathrm{MPa}$ tensile strength [13-15]. Due to these merits, TRIP steels are used for mostly body-in-white in automotive applications, up to a maximum of $65 \%$, and in rail frames, rail roofs, front and rear rails, seat frames, engine cradles, crash box, etc. TRIP steels are replacing DP steels due to their high energy absorption ability with deep drawing.

\subsubsection{TWIP Steel}

TWIP steels possess a high Mn fraction (17-24\%) and are completely austenitic at room temperatures. The formation of deformation twins accompanied in this steel causes enhanced plasticity. The twinning induces a high instantaneous hardening with finer microstructure. The resultant twin 
boundaries strengthen the steel. TWIP steels have a tensile strength of about $1000 \mathrm{MPa}$ and a total elongation can reach $50 \%$ as compared to TRIP steel at a hardening exponent value of 0.4 [16].

\subsubsection{Martensitic Steel}

Martensitic steels are produced during the hot-rolling or annealing of steels and are quenched to completely render them to the martensitic phase. The microstructure contains the martensite with small amounts of ferrite and/or bainite. Among multiphase steels, MS steels show the highest tensile strengths $(\approx 1700 \mathrm{MPa})$. MS steels are often tempered to improve ductility and formability at high strengths [17].

\subsection{The Necessity of Zn-Coated Steel}

Due to the increase in the vehicle warranty period, the application of galvanized steel for corrosion protection has increased dramatically. It is recommended that $30-100 \%$ of the car body should be fabricated by galvanized steels in order to provide more reliable products to customers [18]. Therefore, not only non-coated steels but also galvanized high-strength steels are being developed at the same time. The main processes of Zn coating are usually hot-dip galvanized (GI), galvannealed (GA), and electro-galvanized (EG) processes. In this review, we will discuss Zn-coated TRIP steels and spot-welding issues. However, before proceeding further, we shall elaborate a short discussion on the zinc coating or galvanization process.

\subsubsection{Galvanized Steel (GI)}

Galvanizing means applying a thin layer of zinc to steel or iron for better surface protection. Mostly, the galvanization is performed by the hot-dip galvanizing process. GI steel is the simplest of all and economical due to the hot-dip galvanizing. The presence of zinc protects the steel by acting as a sacrificial electrode and results in a long-lasting steel product [19].

\subsubsection{Galvannealed Steel (GA)}

GA steels have come a long way for steel sheets in auto parts due to their excellent corrosion resistance, paintability, and weldability. The process is similar to GI steels, but annealing is done to improve the formability and paintability. The diffused iron in the coating is found to have a better joining ability in resistance spot welding (RSW). Therefore, galvannealed steels are especially used when joining is difficult with other coatings [20].

\subsubsection{Electro-galvanized Steel (EG)}

EG steels utilize electroplating for the coating of the zinc layer on cold-rolled steel. EG steels are particularly well-suited for exposed auto parts. Similar to other galvanized coatings, EG ones show good adhesive bonding to the metal. The following sections deal with the issues related to TRIP steels concerning Liquid Metal Embrittlement (LME) in RSW [21].

\section{Liquid Metal Embrittlement (LME)}

LME is the loss of reduction in ductility of metals under the exposure to liquid metal, for example steel-Cu, stainless steel- $\mathrm{Zn}$, aluminum-Hg. When steel is heated at a temperature above $400{ }^{\circ} \mathrm{C}$, LME occurs due to the stresses developed and crack propagation at temperatures greater than $750{ }^{\circ} \mathrm{C}$ [22]. The liquid (coating metal) and steel should be in contact with each other for LME to proceed. The composition change in coating type and/or liquid metal often assert significant changes in LME. The results can be either a reduction or an increase in LME. A change in the steel type often results in either no or negligible effect on LME. We will review the various issues in LME related to TRIP steel in RSW industries. 


\subsection{Resistance Spot Welding}

In the vehicle industry, RSW is mostly used to weld TRIP steel, TWIP steels, GI steels, etc. The process is very simple and rapid, shorter than $1 \mathrm{~s}$ to weld one single spot [23]. More than 3000 spots are welded for assembling a single autobody [24]. The major advantage of RSW is that it is easy to automate and it is inexpensive to install welding production facilities. It is even available to apply stainless steel/aluminum/low carbon steel dissimilar bonding [25]. RSW is affected by various factors, e.g., the resistance of sheet interface, weld current and welding time, electrode force, etc. The most sensitive parameter is the weld current range, for instance, 4-11 kA [26]. If an excessive current which is higher than the suitable range is applied to the steel sheet, the expulsion of material could occur. Therefore, a response surface methodology is sometimes used to figure out the proper welding conditions [27-29].

One of the major problems in commercializing galvanized TRIP steel as an autobody are LME phenomena. During RSW, molten Zn easily infiltrates the grain boundaries of the steel surface. Cracks are created and induce brittle fracture, especially when compared to bare welded steel. This degrades the welding quality. It is widely known that LME develops due to several factors: liquid Zn, LME-susceptible metal alloys, and welding conditions. Figure 2 depicts the combined factors that make galvanized steels sensitive to LME.

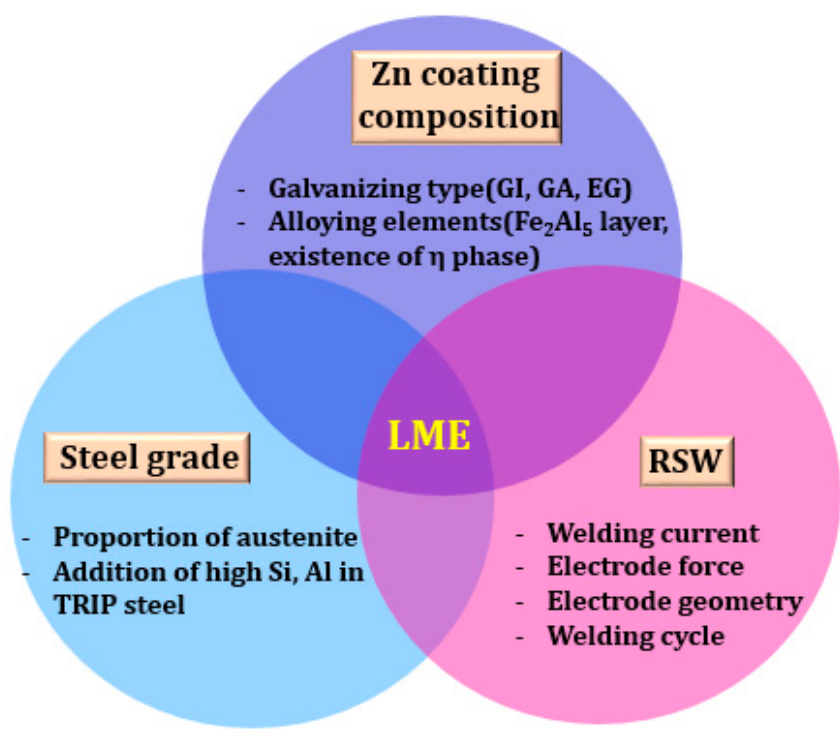

Figure 2. Conditions for the occurrence of Liquid metal embrittlement (LME).

Among the various welding techniques, RSW occupies around 90\% of the assembly work of steel in automotive vehicles [30]. RSW is mostly used to weld the steel sheets in automotive applications. According to the Pareto curve, about $80 \%$ of weld defects come from the $20 \%$ cause [31]. The spot-welding assembly cost is $\$ 21,430,536$, which is $\$ 21.79$ per vehicle. This is estimated to be $4.58 \$ / \mathrm{kg}$ [32]. There have not been enough LME studies about TRIP steel compared to TWIP or DP steel. Therefore, this paper is focused on reviewing investigations mostly on the LME of TRIP steels.

\subsection{LME Studies on Galvanized TRIP Steel}

Figure 3 presents the diverse steel types and LME studies related to TRIP steels. It can be noticed that TRIP steel is classified as an AHSS.

Table 1 summarizes the welding conditions for RSW of TRIP steel. It is known that 6-12 kA weld current is set as a suitable current range [33,34]. If the weld current is higher than this range, the expulsion of molten Zn during RSW occurs and the quality of welds is degraded. Welding properties are also investigated with several welding parameters such as electrode force, electrode geometry, 
type of Zn coating, weld time, etc. All of these parameters are generally known to affect the LME of TRIP steel. It is noticeable that the results of Kim and Choi contradict Zhou's observation that the effect of increasing the electrode force is inversely related to LME crack growth [34-40].

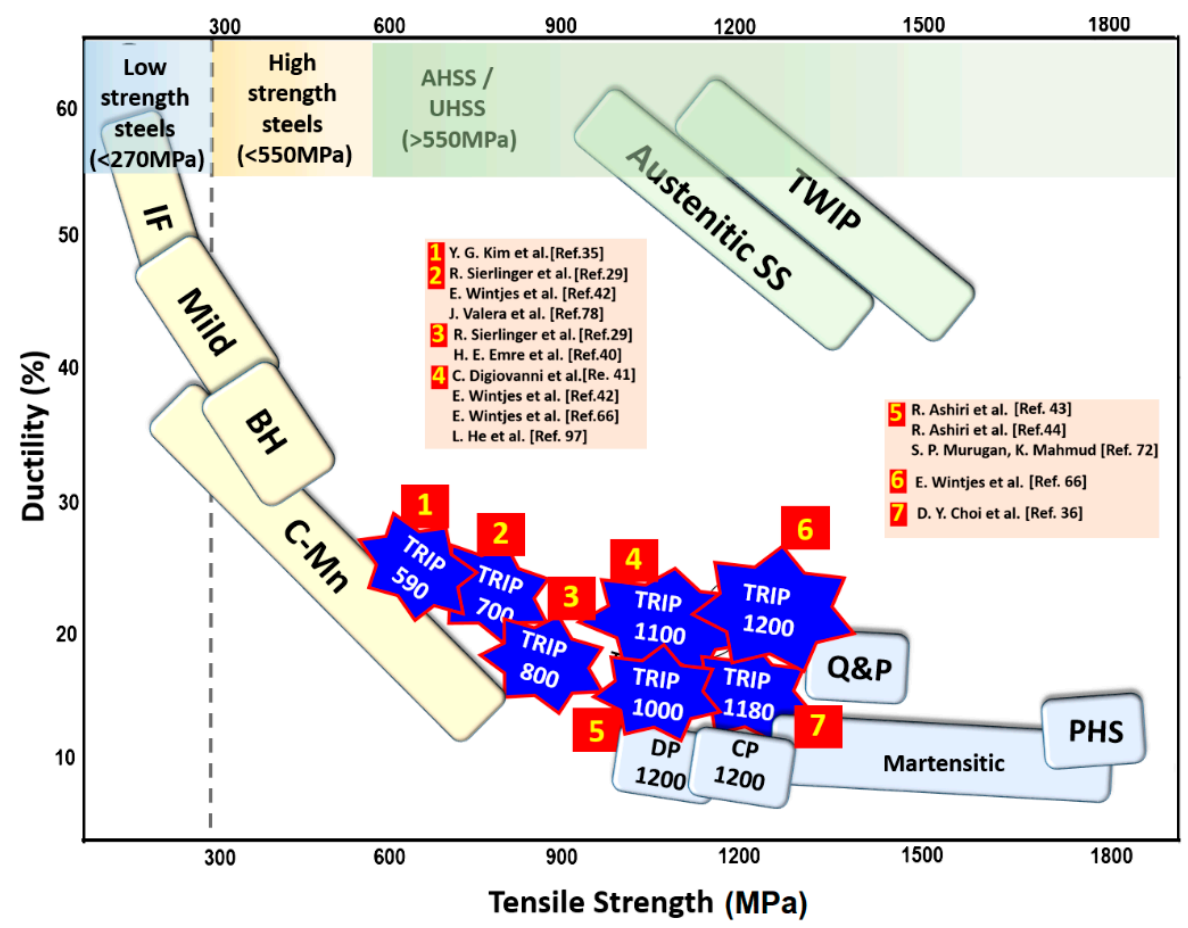

Figure 3. LME studies of several transformation-induced plasticity (TRIP) sheets of steel. IF $=$ Interstitial free, $\mathrm{BH}=$ Bake hardening, $\mathrm{Q} \& \mathrm{P}=$ Quenching and partitioning, $\mathrm{PHS}=$ Press hardenable steel. Adapted from [33], with permission from Taylor and Francis, 2018, http://www.tandfonline.com/.

Table 1. Studies for LME of resistance spot-welded TRIP steel.

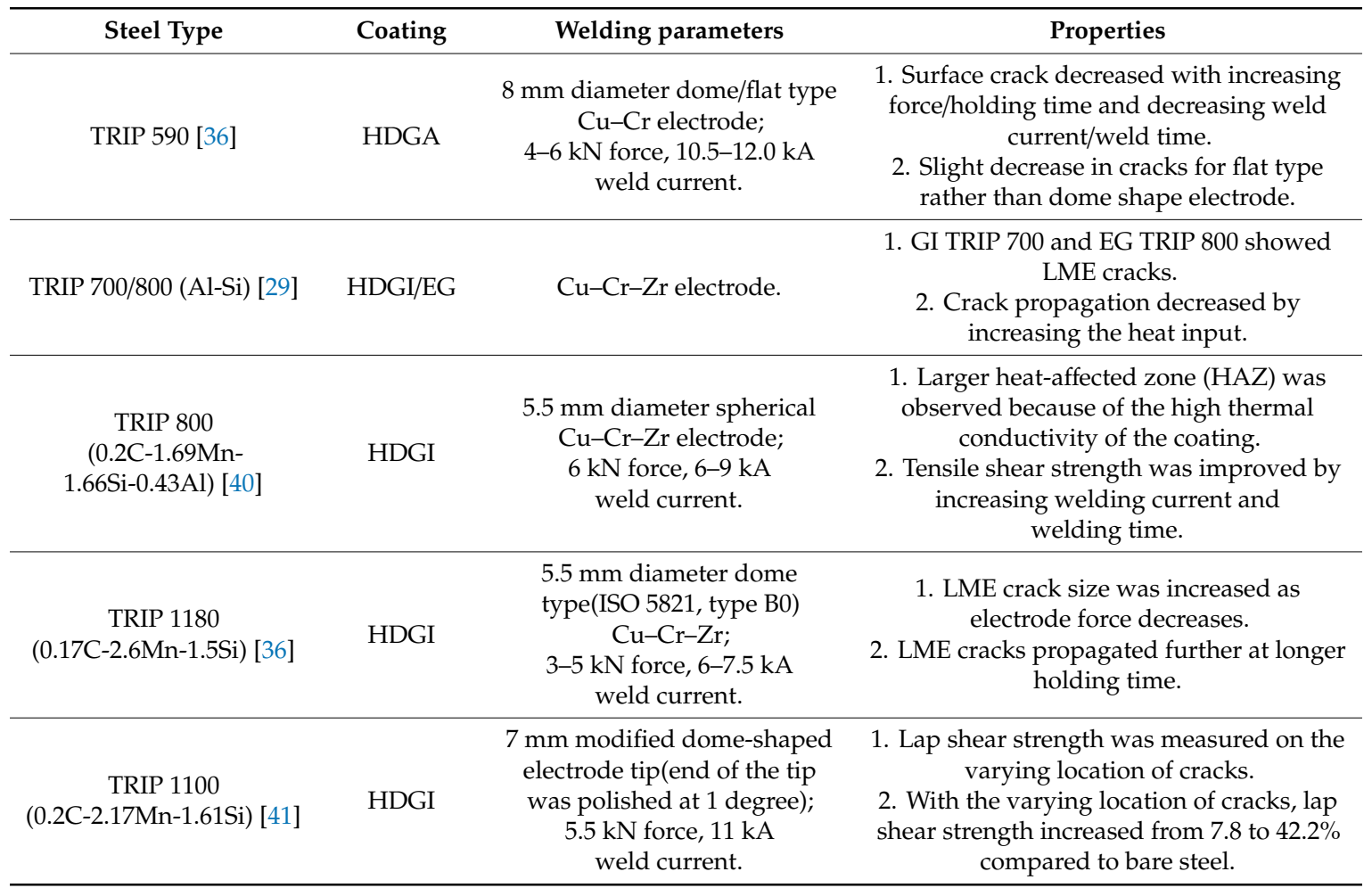


Table 1. Cont.

\begin{tabular}{|c|c|c|c|}
\hline Steel Type & Coating & Welding parameters & Properties \\
\hline $\begin{array}{c}\text { TRIP } 690 \\
(0.2 \mathrm{C}-1.7 \mathrm{Mn}-0.4 \mathrm{Si}-1.31 \mathrm{Al}) \\
\text { TRIP } 1100 \\
(0.2 \mathrm{C}-2.2 \mathrm{Mn}-1.6 \mathrm{Si}) \\
\text { TRIP } 1200 \\
(0.22 \mathrm{C}-2.3 \mathrm{Mn}-1.7 \mathrm{Si})[42]\end{array}$ & HDGI & $\begin{array}{l}\text { 6-7 mm diameter electrode, } \\
\text { female B-type electrode caps; } \\
3.6-5.5 \mathrm{kN} \text { force, } 10-10.5 \mathrm{kA} \\
\text { weld current. }\end{array}$ & $\begin{array}{l}\text { 1. Tensile lap shear strength decreased for } \\
\text { the welds in TRIP. } \\
\text { 2. Multiplying lognormal median crack } \\
\text { length by the number of cracks per weld } \\
\text { was suggested to explain the critical } \\
\text { crack location. }\end{array}$ \\
\hline $\begin{array}{c}\text { TRIP } 1000 \\
(0.26 \mathrm{C}-2.18 \mathrm{Mn}- \\
1.09 \mathrm{Si}-0.52 \mathrm{Al})[43]\end{array}$ & HDGA & $\begin{array}{l}6 \mathrm{~mm} \text { diameter dome-radius } \\
\text { type } \mathrm{Cu}-\mathrm{Cr} \text { electrode tip; } \\
4 \mathrm{kN} \text { force, } 4-10 \mathrm{kA} \\
\text { weld current. }\end{array}$ & $\begin{array}{l}\text { 1. Higher nugget penetration depth } \\
\text { resulted in higher tensile shear strength and } \\
\text { cross tensile strength. }\end{array}$ \\
\hline $\begin{array}{c}\text { TRIP } 1000 \\
\text { (C-Mn-Si-Al) [44] }\end{array}$ & HDGA & $\begin{array}{l}6 \mathrm{~mm} \text { diameter dome-radius } \\
\text { type } \mathrm{Cu}-\mathrm{Cr}- \\
\mathrm{Zr} \text { electrode tip; } \\
4 \mathrm{kN} \text { force, } 4-10 \mathrm{kA} \\
\text { weld current. }\end{array}$ & $\begin{array}{l}\text { 2. Weld discontinuities and defects } \\
\text { are created. } \\
\text { 3. With higher than critical welding current, } \\
\text { tensile strength (CTS) and tensile shear } \\
\text { strength (TSS) are degraded. }\end{array}$ \\
\hline
\end{tabular}

\section{Note: HDGI: hot-dip galvanized, HDGA: hot-dip galvannealed, EG: electro-galvanized, MFDC: medium frequency} direct current.

There are not enough microstructural analyses of cracks formed in galvanized TRIP steels. Since LME cracks are generated during a very short welding cycle, it is almost impossible to observe the origin of the cracks. Figure 4 presents various types of macrocracks formed on galvanized TRIP steel during RSW. The cracks propagate from the various locations marked A, B, and C (Figure 4a). The corresponding microstructures of the spot welds are shown in Figure $4 \mathrm{~b}$. Choi et al. found a $\mathrm{Zn}$-rich surface in the vicinity of the cracks. Kim et al. argued that the $\mathrm{Cu}$ was dissolved from the $\mathrm{Cu}-\mathrm{Cr}$ electrode and diffused to form brittle $\mathrm{Cu}_{5} \mathrm{Zn}_{8}$ as reaction compounds at the crack interface $[35,36,45]$.

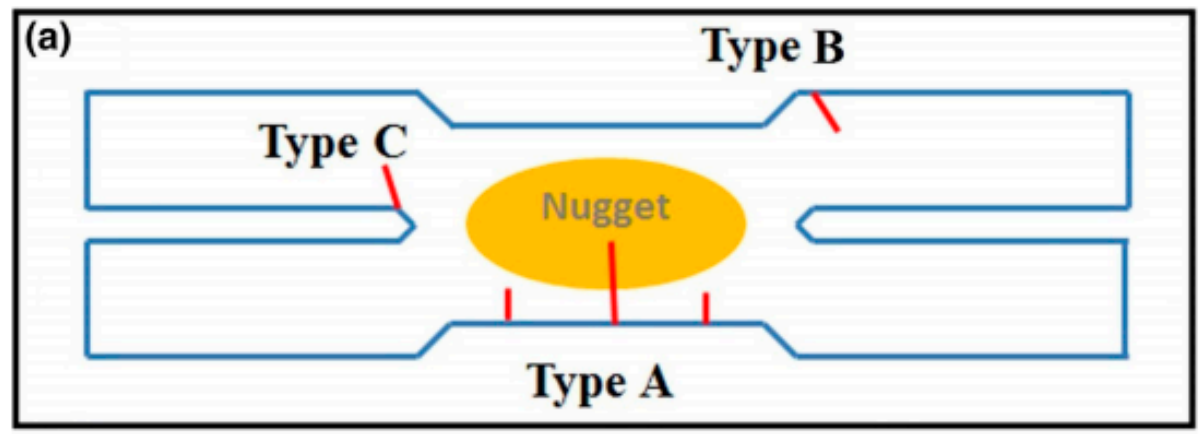

(b)

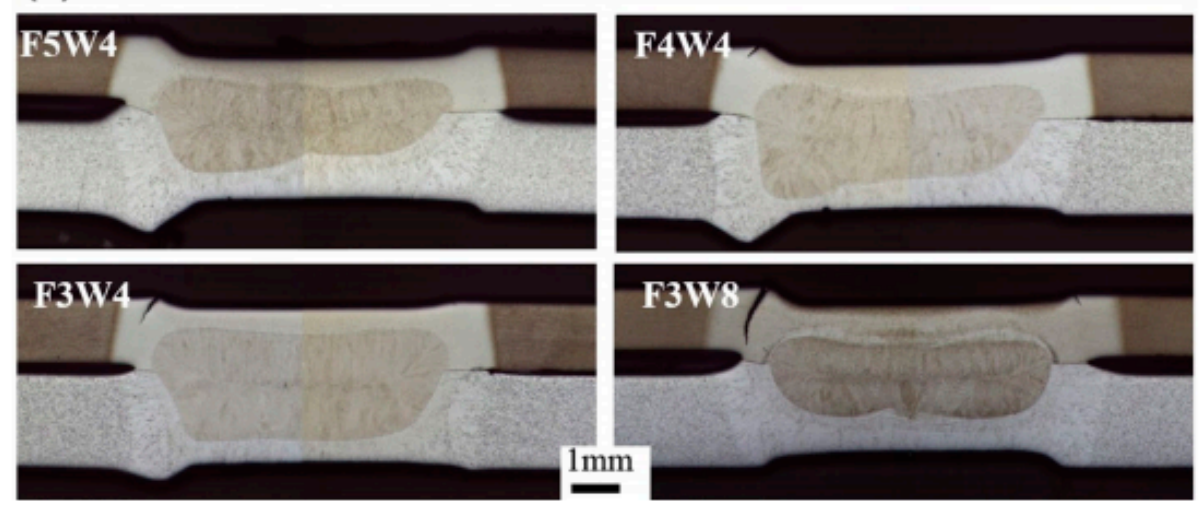

Figure 4. (a) Schematic diagram for classification of LME cracks at various locations, and (b) cross-sectional microstructures of spot welds at various electrode force and time. Reprinted with permission of [36], Springer, 2018. 


\section{Galvanized TRIP Steel and LME Issues}

\subsection{TRIP Steel}

As already mentioned, TRIP steel is composed of a multiphase microstructure composed of ferrite, bainite, and retained austenite which is similar to DP steel. DP steel shows better strength, shock absorption, and higher ductility compared to conventional low-carbon steel for automobiles. However, DP steels are known to have plastic anisotropy issues [46]. Therefore, multiphase TRIP steel has the advantages of uniform elongation derived from martensite transformation. Choi et al. reported $1 \mathrm{wt} \% \mathrm{Cu}$ addition in high Mn steel $(0.4 \mathrm{C}-15 \mathrm{Mn}-(0,1,2) \mathrm{Cu})$ showed both a TRIP and TWIP effect simultaneously $[47,48]$. The hardening rate dropped abruptly immediately after yielding because of the absence of initial $\alpha^{\prime}$-martensite and then increased by activating the transformation of $\alpha^{\prime}$-martensite and twinning. This steel showed a tensile strength of $1096 \mathrm{MPa}$ and an elongation of $65.1 \%$. Figure 5 shows the microstructure of $1 \mathrm{Cu}$ steel during the deformation stage. It can be seen that the transformation of $\alpha^{\prime}$-martensite occurs at a deformation twin (Figure 5).
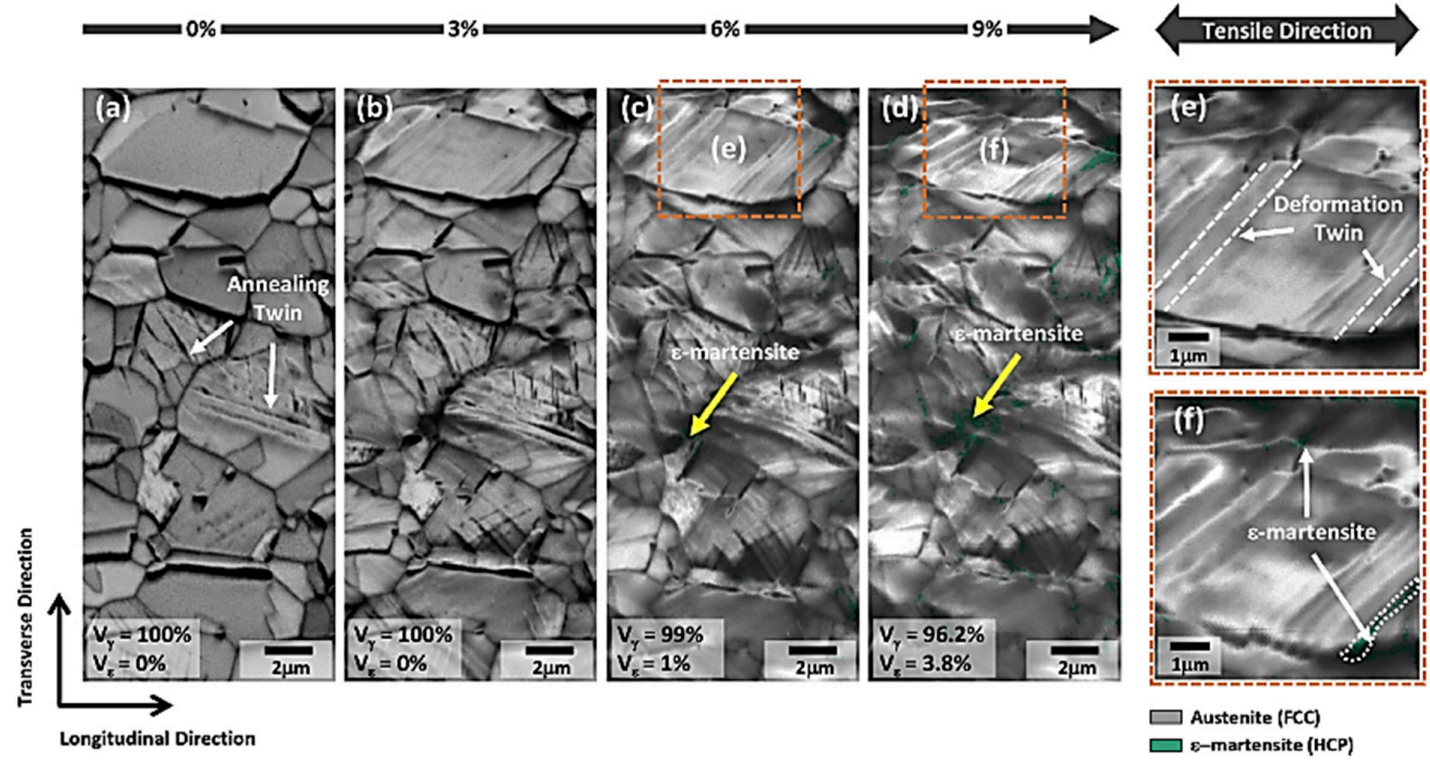

Figure 5. Microstructural evolution of $1 \mathrm{wt} \% \mathrm{Cu}$-added steel at the early deformation stage: electron backscatter diffraction IQ maps with phase identification of the areas deformed after the interrupted tensile test at engineering strains of (a) $0 \%$, (b) 3\%, (c) $6 \%$, and (d-f) $9 \%$ for the $1 \mathrm{wt} \%$ Cu steel. At the strain of $6 \%$, the $\varepsilon$-martensite starts to form and grow. (e,f) High-magnification maps of the dashed boxes in (c,d), respectively. Sub-microstructures composed of parallel lines, i.e., deformation twins, are developed inside an austenite grain. The $\varepsilon$-martensite also forms at an austenite grain boundary and a deformation twin. Reprinted from [47], with permission of Elsevier, 2019.

Figure 6 shows one example of a fabrication process of TRIP steel. The galvanization process of TRIP steel is given by Maki et al. [49]. The multiphase microstructure is usually fabricated by the heat treatment process following two steps: first, inter-critical annealing between $\mathrm{Ac}_{1}$ to $\mathrm{Ac}_{3}\left(780-880{ }^{\circ} \mathrm{C}\right)$ for $1 \mathrm{~min}$, followed by quenching; second, the isothermal transformation between $350-500{ }^{\circ} \mathrm{C}$ for 2-3 min [50]. After the first treatment, a microstructure which contains a similar proportion of austenite and ferrite is created. During the second isothermal treatment, most of the austenite is transformed into bainite. Finally, TRIP steel contains 50-60 wt $\%$ ferrite, $25-40 \mathrm{wt} \%$ bainite, and $5-15 \mathrm{wt} \%$ of retained austenite. More than half of the retained austenite is transformed into martensite during the elongation of TRIP steel [51].

During the inter-critical annealing process, the carbon enrichment of austenite takes place. If carbon does not precipitate out as carbide during isothermal treatment, the carbon concentration 
goes to retained austenite. Carbon-rich austenite is thus very effective in lowering the martensite formation temperature (Ms) $[11,52,53]$. The additives $\mathrm{Si}$ and $\mathrm{Al}$ suppress the precipitation of carbon during this process $[12,13,54]$. The addition of $\mathrm{Mn}$ assists the retained austenite to fully transform it into martensite [49]. Since $\mathrm{Si}$ forms $\mathrm{SiO}_{2}$ at the surface of TRIP steel during galvanizing, the addition of $\mathrm{Al}$ in TRIP steel has been widely investigated $[48,55,56]$.

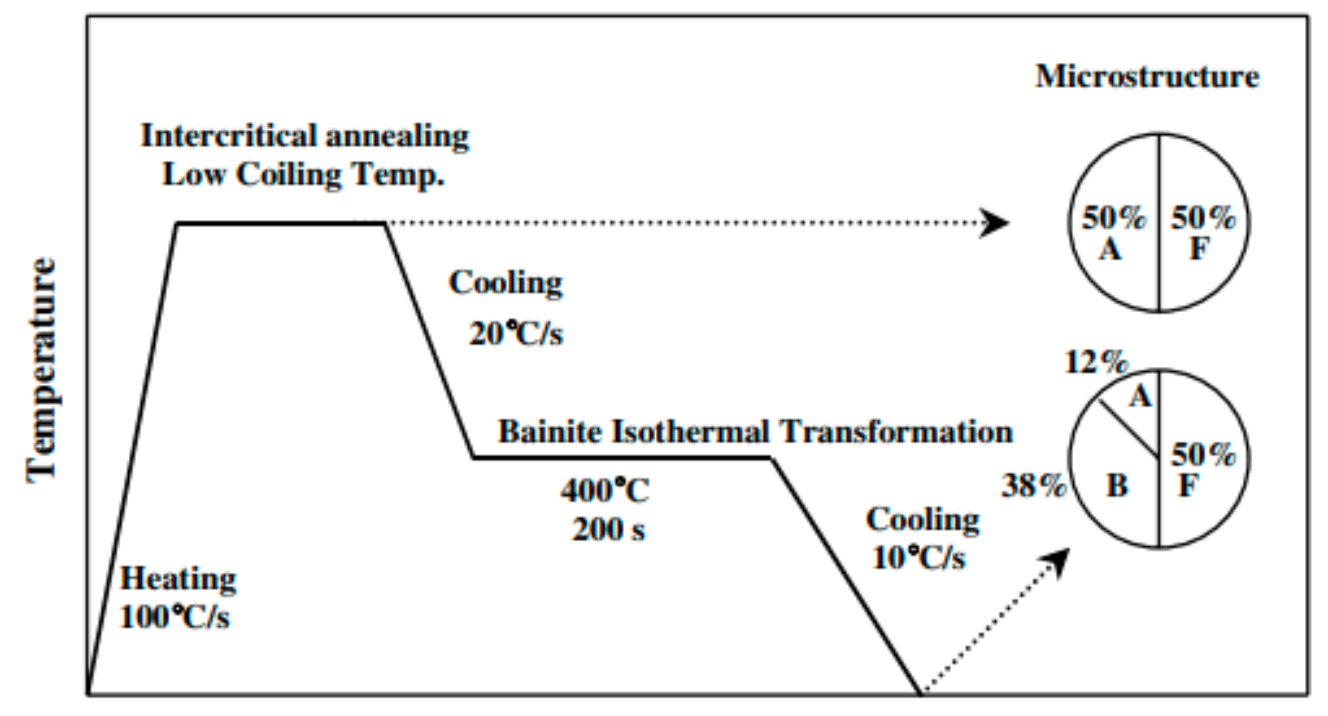

Time

Figure 6. Heat treatment process of TRIP steel: the inter-critical annealing and isothermal transformation processes. A is austenite, F is ferrite, B is Bainite. Reprinted from [48], with permission of Elsevier, 2006.

\subsection{Issues of Galvanized TRIP Steels}

The presence of $\mathrm{Mn}$ and $\mathrm{Si}$ in TRIP steel forms $\mathrm{Mn}_{2} \mathrm{SiO}_{4}, \mathrm{SiO}_{2}$ selectively at the steel surface during galvanizing. These oxides degrade the quality of the $\mathrm{Zn}$ coating $[57,58]$. To prevent this phenomenon, $\mathrm{Al}$ is considered as a replacement of $\mathrm{Si}$. Al has been shown to improve wettability during hot-dip galvanizing. Jacques et al. fabricated 1.5Si- and 1.5Al-alloyed TRIP steels [59]. In their investigation, the addition of $\mathrm{Al}$ was effective for inhibiting $\mathrm{Fe}_{3} \mathrm{C}$ (cementite) and keeping the austenite at room temperature. During the TRIP effect, Al-alloyed steel did not show solid-solution strengthening because of the low melting point of Al, while Si-alloyed steel showed a TRIP effect even at a low strength level. Table 2 is presented to classify the types of galvanizing process and its properties. It is noteworthy that CMnAlSi or CMnAl TRIP steels serve as a better replacement of CMnSi TRIP steel because of wetting issues and selective oxidation during galvanizing. 
Table 2. Classification of process, steel and properties of galvanizing steels.

\begin{tabular}{|c|c|c|}
\hline Galvanizing & Steel Type & Galvanizing Property \\
\hline HDGI & $\begin{array}{c}\text { CMnSi TRIP steel } \\
\text { (0.19C-1.57Mn-1.46Si) [60] }\end{array}$ & $\begin{array}{l}\text { 1. } \mathrm{Zn}-0.2 \mathrm{Al}, 460^{\circ} \mathrm{C} \text { bath. } \\
\text { 2. Island-like features at the grain boundary of ferrite } \\
\text { and austenite resulting from high solubility of } \mathrm{Si} \\
\text { in ferrite. }\end{array}$ \\
\hline HDGI & $\begin{array}{l}\text { 0.2C-1.52Mn-0.45Si-1.0Al TRIP } \\
\text { steel [49] }\end{array}$ & $\begin{array}{c}\text { 1. } \mathrm{Zn}-0.2 \mathrm{Al}, 460{ }^{\circ} \mathrm{C} \text { bath. } \\
\text { 2. At }-53,-30{ }^{\circ} \mathrm{C} \text { dew point, the aluminothermic } \\
\text { reduction occurred to form } \mathrm{Fe}_{2} \mathrm{Al}_{5-\mathrm{x}} \mathrm{Zn}_{\mathrm{x}} \text { layer while } \\
\text { at }+5^{\circ} \mathrm{C} \text { dew point a bare area was noticed } \\
\text { after dipping. }\end{array}$ \\
\hline HDGI & $\begin{array}{c}\text { CMnAl TRIP steel } \\
(0.18 \mathrm{C}-1.56 \mathrm{Mn}-1.73 \mathrm{Al})[61]\end{array}$ & $\begin{array}{l}\text { 1. } \mathrm{Zn}-0.2 \mathrm{Al}, 460^{\circ} \mathrm{C} \text { bath. } \\
\text { 2. Dew points were }+10,-30,-50^{\circ} \mathrm{C} \text {. Al substituted } \\
\text { the Si and oxidized internally during hot-rolling, } \\
\text { showed limited } \mathrm{Al} \text { contents at surface. }\end{array}$ \\
\hline HDGI & $\begin{array}{l}\text { CMnSi-Bi TRIP steel } \\
(0.08 \mathrm{C}-1.64 \mathrm{Mn}-1.48 \mathrm{Si}- \\
0.04-0.19 \mathrm{Bi})[62]\end{array}$ & $\begin{array}{l}\text { 1. } \mathrm{Zn}-0.22 \mathrm{Al}, 460^{\circ} \mathrm{C} \text { bath. } \\
\text { 2. The addition of Bi could control the surface } \\
\text { oxidation. The thickness of Mn-enriched oxide layer } \\
\text { decreased with addition of Bi. }\end{array}$ \\
\hline HDGA & $\begin{array}{c}\text { TRIP steel } \\
(0.1 \mathrm{C}-1.49 \mathrm{Mn}-1.22 \mathrm{Si}-0.04 \mathrm{Al}) \text { [55] }\end{array}$ & $\begin{array}{l}\text { 1. } \mathrm{Zn}-0.14-0.18 \mathrm{Al}, 460{ }^{\circ} \mathrm{C} \text { bath. } \\
\text { 2. It was concluded that } \mathrm{MnSiO} \mathrm{O}_{3} \text { and } \mathrm{Mn}_{2} \mathrm{SiO}_{4} \text { were } \\
\text { reduced by } \mathrm{Al} \text { to form voids. Then Fe surface was } \\
\text { dissolved to form } \mathrm{Fe}_{2} \mathrm{Al}_{5} \text { layer. }\end{array}$ \\
\hline HDGA & $\begin{array}{l}\text { Mn-Al TRIP steel (1.7Mn-1.5Al), } \\
\text { high Mn alloyed steel (23Mn) [63] }\end{array}$ & $\begin{array}{l}\text { 1. } \mathrm{Zn}-0.14 \mathrm{Al}-0.035 \mathrm{Fe}, 460^{\circ} \mathrm{C} \text { bath, } \\
\text { 2. Galvannealed at } 500-600{ }^{\circ} \mathrm{C} \text { for } 15 \mathrm{~s} \text {. Compared to } \\
\text { low alloy steel, galvannealing kinetics become slower } \\
\text { at high } \mathrm{Mn} \text { alloyed steel. }\end{array}$ \\
\hline HDGA & CMnSi TRIP steel (2.2Mn-1.4Si) [64] & $\begin{array}{c}\text { 1. } \mathrm{Zn}-0.13 \mathrm{Al}, 460{ }^{\circ} \mathrm{C} \text { bath, } \\
\text { 2. Galvannealed at } 540 \text { to } 570{ }^{\circ} \mathrm{C} . \delta\left(\mathrm{FeZn} \mathrm{F}_{10}\right) \text { and } \\
\eta(\mathrm{Zn}) \text { layer were found at }-60,-30{ }^{\circ} \mathrm{C} \text { dew point atm } \\
\text { annealed steel, while } \delta \text { and } \Gamma\left(\mathrm{Fe}_{3} \mathrm{Zn}_{10}\right), \Gamma_{1}\left(\mathrm{Fe}_{11} \mathrm{Zn}_{40}\right) \\
\text { layer were found at each }-10,0,5^{\circ} \mathrm{C} \text { dew point } \\
\text { annealed one. }\end{array}$ \\
\hline EG & $\begin{array}{c}\text { CMnSi (0.19C-1.57Mn-1.46Si), } \\
\text { CMnAlSi } \\
\text { (0.31C-1.57Mn-0.34Si-1.23Al) TRIP } \\
\text { steel [65] }\end{array}$ & $\begin{array}{c}\text { 1. Hydrogen atoms are absorbed to the TRIP steel } \\
\text { surface because of high } \mathrm{H} \text { solubility in austenite } \\
\text { during electro-galvanizing, resulting in } \\
\text { H embrittlement. }\end{array}$ \\
\hline
\end{tabular}

Note: HDGI: hot-dip galvanized, HDGA: hot-dip galvannealed, EG: electro-galvanized.

\section{Resistance Spot Welding and LME Issues}

\subsection{Principle of Resistance Spot Welding and the Effect on LME}

In the autobody assembly line, RSW is widely used since it takes less than $1 \mathrm{~s}$ to make one weld nugget, and the cooling rate of the nugget is higher than $1000{ }^{\circ} \mathrm{C} / \mathrm{s}$. Therefore, the whole welding process has a very high productivity. Moreover, the RSW processing line is much less expensive compared to laser welding and is easy to adapt to an automated process. Resistance heat input (Q) during RSW, is given as following proportional expression [66]:

$$
\mathrm{Q} \propto\left(R_{1}+R_{2}\right) \cdot I^{2} \cdot s \cdot r^{-4}
$$

where, $R_{1}$ is the contact resistance of two metal sheets in ohm, $R_{2}$ is the metal sheet's electrical resistance in ohm, $I$ is weld current in amperes, $s$ is welding time in seconds, $r$ is the contact diameter of the two sheets in millimeters. $I, s, r$ are available to change depending on the welding situation and these parameters have a major impact on the LME. The weld time could control the heat input 
by alternating the current pulse. Wintjes et al. analyzed the effect of heat input on the coating composition [66,67]. It was revealed that a longer pulse followed by a shorter pulse reduced the LME significantly (e.g., 14-2-10 cycle schedule). Since a longer pulse applied enough heat input to zinc coating, more diffusion of Fe into zinc coating occurred than in the shorter ones, and coating became stabilized, leading to a reduction in LME cracks.

Figure 7 shows a schematic of resistance and temperature distributions of two steel sheets during RSW. The attached part of the two sheets shows the highest resistance. Therefore, the weld pool (or nugget) shows the highest temperature $[36,68]$. The contact part between the surface of the steel sheet and electrode also shows pretty high resistance and temperature.

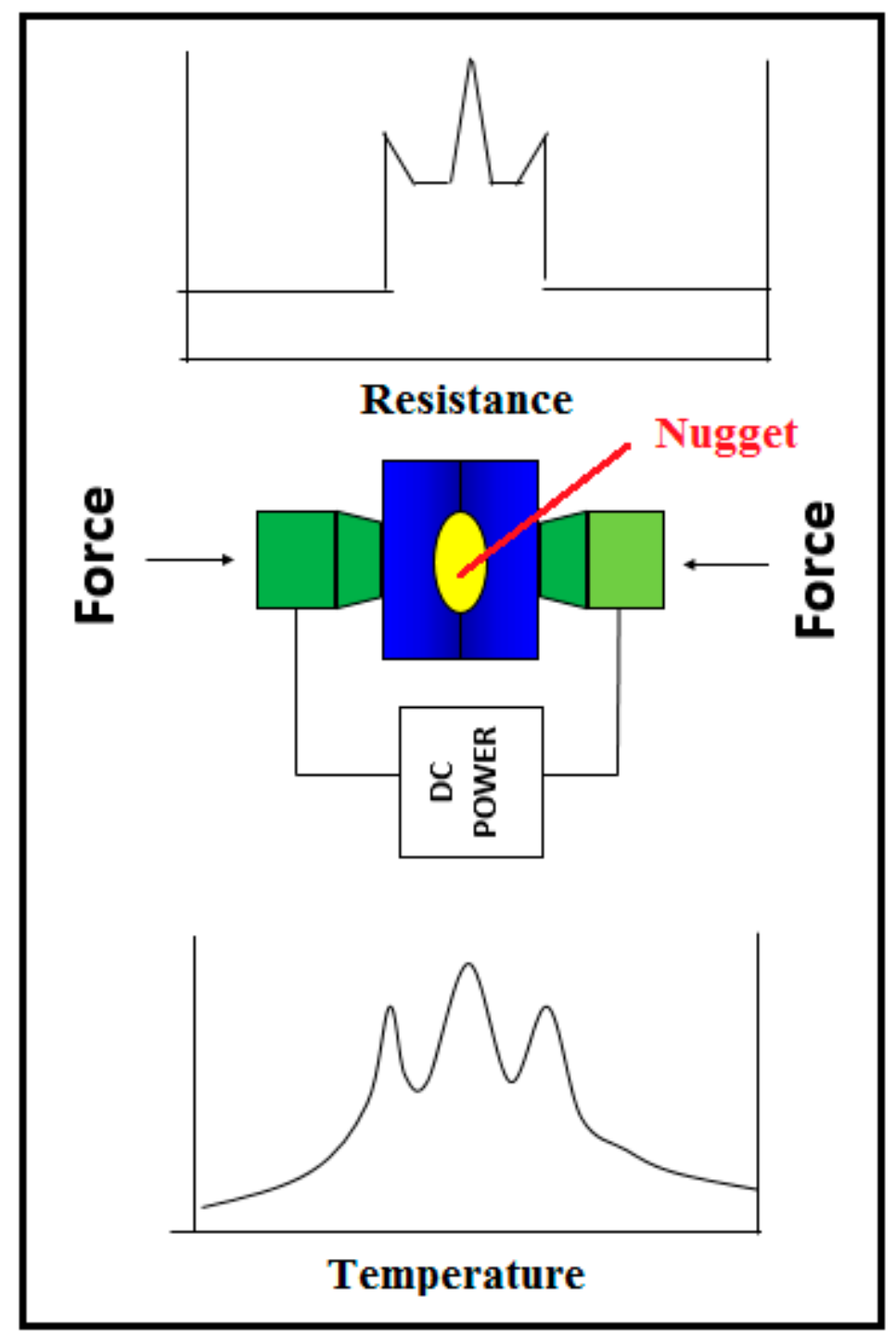

Figure 7. Resistance and temperature distributions of electrode and steel sheets.

This is explained as the oxidation and high roughness of the electrode and the surface of steel sheet cause a higher contact resistance. To suppress LME, the parameters of welding, such as welding force [35,37,69,70], welding time [71], weld current [72] and weld electrode geometry [29,72-76], were regularly studied, including the effect of coating types as well $[67,74]$.

\subsection{Parameters of Resistance Spot Welding on LME}

Figure 8 presents the process of RSW, which consists of squeezing, welding, and holding. The $\mathrm{Cu}-\mathrm{Cr}$ electrode usually exerts contact pressure on the sheets during the squeezing stage. 
This pressure is maintained until the hold time ends. After the squeezing stage, a welding current is applied from the electrode to the steel sheet during the weld time. The contact part of the steel sheet melts and a nugget is created. The nugget cools down very fast at the rate of $500-1000{ }^{\circ} \mathrm{C} / \mathrm{s}$ because of the cooling water surrounding the electrode.

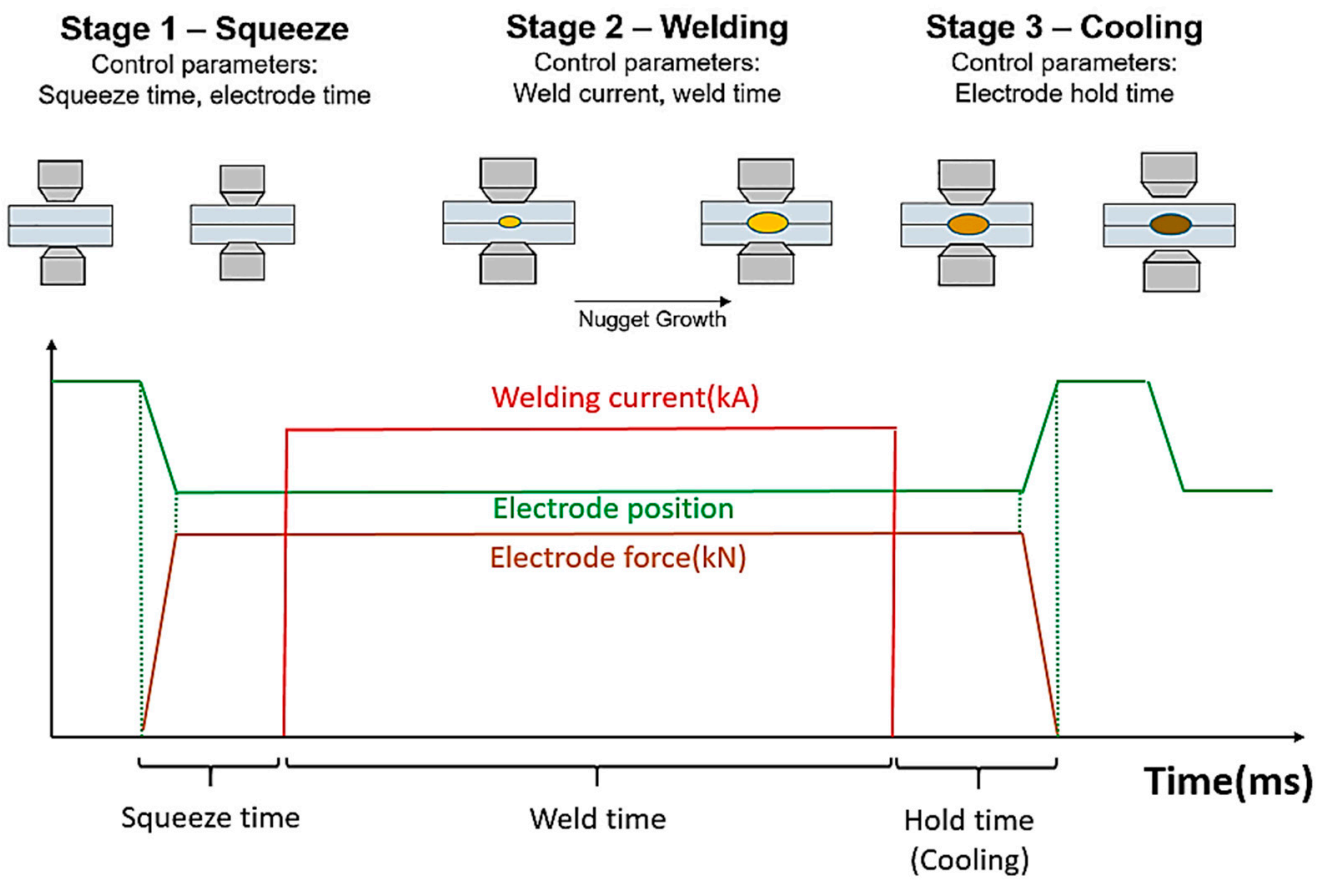

Figure 8. The process of resistance spot welding. Reprinted from [33], with permission of Taylor and Francis, 2018, http://www.tandfonline.com.

During the RSW process, the parameters that most affect the welding quality are the welding current, welding time, and pressure. As noted in Equation (1), the welding current significantly affects the amount of heat. Emre et al. compared the size of a nugget at different current densities $[40,77]$. Hot-dip galvanized TRIP 800 (0.2C-1.69Mn-1.66Si) was welded at a 6,7,8,9 kA welding current at same $6 \mathrm{kN}$ electrode force. After 20 cycles of weld time $(1$ cycle $=0.02 \mathrm{sec}), 6.7,7.2,7.25,8.0 \mathrm{~mm}$ diameter nuggets were made. This shows that a higher current resulted in a higher heat input, which created a larger nugget. However, a welding current higher than the acceptable current range created spatters or pores at the welding joint. Hwang et al. reported that high Al steel (0.3C-3.6Mn-5.1C-0.1Si) was difficult to weld at more than a $5.5 \mathrm{kA}$ welding current because the high $\mathrm{Al}$ content increased the specific resistance of the steel sheet [78]. It caused severe heat input and expulsion took place.

The welding time is also one of the primary factors in creating heat input, $Q$, as noted in Equation (1). It is easy to assume that longer welding time creates larger nuggets and therefore the welding part will show higher tensile strengths. However, a longer welding time even can decrease the tensile strength of the weld part. Valera et al. investigated the tensile strength of the welding zone between TRIP 690 and DP 600 steel (DC-05) at different welding times [78,79]. At the same welding current of $4.75 \mathrm{kA}$ and welding time of $785 \mathrm{~ms}$ gave a tensile strength of $3206 \mathrm{~N}$ which was relatively lower than $3293 \mathrm{~N}$ at $500 \mathrm{~ms}$ of welding time. In their results, there were no significant differences in the diameter of a nugget. This a because a longer welding time can make the expulsion of molten steel and excess fused metal come out of the steel sheet joint. The weld nugget does not grow more and it results in a waste of welding time.

Prior to the application of a welding current, the electrode pressure is required to avoid the expulsion or spatter of the welding part. Higher pressure should be applied for the welding of 
high-strength steel sheets. The wider the contact area between the sheets, the lower contact resistance. Therefore, the welding current or welding time should be properly adjusted.

\section{Liquid Metal Embrittlement and its Suppression}

\subsection{Mechanisms of Zinc Penetration}

Several investigations were proceeded to explain the mechanisms of liquid metal embrittlement (LME) [80-86]. Shunk et al. analyzed sensitivity to LME among several metals, steel (solid)/In (liquid), $\mathrm{Al}$ alloy (solid)/Zn (liquid), and Ti alloy (solid)/Cd (liquid) [86,87]. They suggested "LME specificity", which means, in general, that if the liquid metal has little solubility to the base metal, such as solid Fe-liquid $\mathrm{Zn}$, the wetting phenomena act as a driving force in liquid metal penetrating the grain boundary of the base metal. Therefore, LME occurs very easily. However, if the solubility between the base metal and the liquid metal is high, an intermetallic compound forms and the probability of LME decreases.

In some studies, the embrittlement of steel by molten zinc at $700{ }^{\circ} \mathrm{C}$ was explained as the wetting of grain boundary [88-91]. This means that the molten zinc can penetrate the steel substrate according to the following equation:

$$
\gamma_{G B}>2 \gamma_{S L}
$$

where, $\gamma_{G B}$ is the grain boundary energy of the steel surface and $\gamma_{S L}$ is the solid steel-liquid zinc interface energy. Since zinc infiltration contacts both sides of the grain boundary, factor 2 is multiplied to the interfacial energy. If austenite $\gamma_{G B}$ is known to be $0.4-1.4 \mathrm{~J} / \mathrm{m}^{2}$ [92], while ferrite (bcc) $\gamma_{G B}$ is $0.5-1.6 \mathrm{~J} / \mathrm{m}^{2}$ [65]. If $\gamma_{G B}$ is higher than $2 \gamma_{S L}$, zinc penetration will be facilitated by wetting into the grain boundaries of the steel surface. In that aspect, $\gamma_{G B}$ of ferrite is higher than that of austenite and contradicts each other. It is widely known that austenitic TRIP steel shows greater LME sensitivity compare to conventional mild steel. However, this can be explained, as it needs a higher force to weld galvanized TRIP steel. A suitable electrode force to remove the gap between steel sheets is considered as per the following equation $[36,52,93,94]$ :

$$
\mathrm{P}=2.45 \cdot \mathrm{t} \cdot(T S / 300)^{1 / 2}
$$

where $\mathrm{P}$ is the electrode force in $\mathrm{kN}$, $\mathrm{t}$ is the sheet thickness in $\mathrm{mm}$, and TS is the tensile strength of the steel sheet in MPa. If the tensile strength of steel increases, a higher electrode force is required to form a big sized weld nugget. Then, severe tensile stress is applied at the shoulder of indentation, and this will affect the propagation of LME cracks [34,95].

\subsection{Liquid Metal Embrittlement of TRIP Steel}

\subsubsection{Influences to LME Sensitivity}

There are some research activities on TWIP steel LME sensitivity with respect to coating type $[74,76,96]$. Ashiri et al. have explained that hot-dip GI steels show higher sensitivity compared to hot-dip GA or EG ones [74,76]. The weldable current range was set for the emergence of cracks smaller than $10 \mu \mathrm{m}$. The difference in welding current with or without the occurrence of LME was investigated. The reduction of the weldable current range was highest for GI steel. This can be explained as GI coating is the most susceptible to LME. However, there are only a few investigations that compare LME sensitivity among GI-, GA-, and EG-coated TRIP steel, as shown in Figure 9 [36,70,72,97]. A more detailed discussion of the effect of coating type is required. 


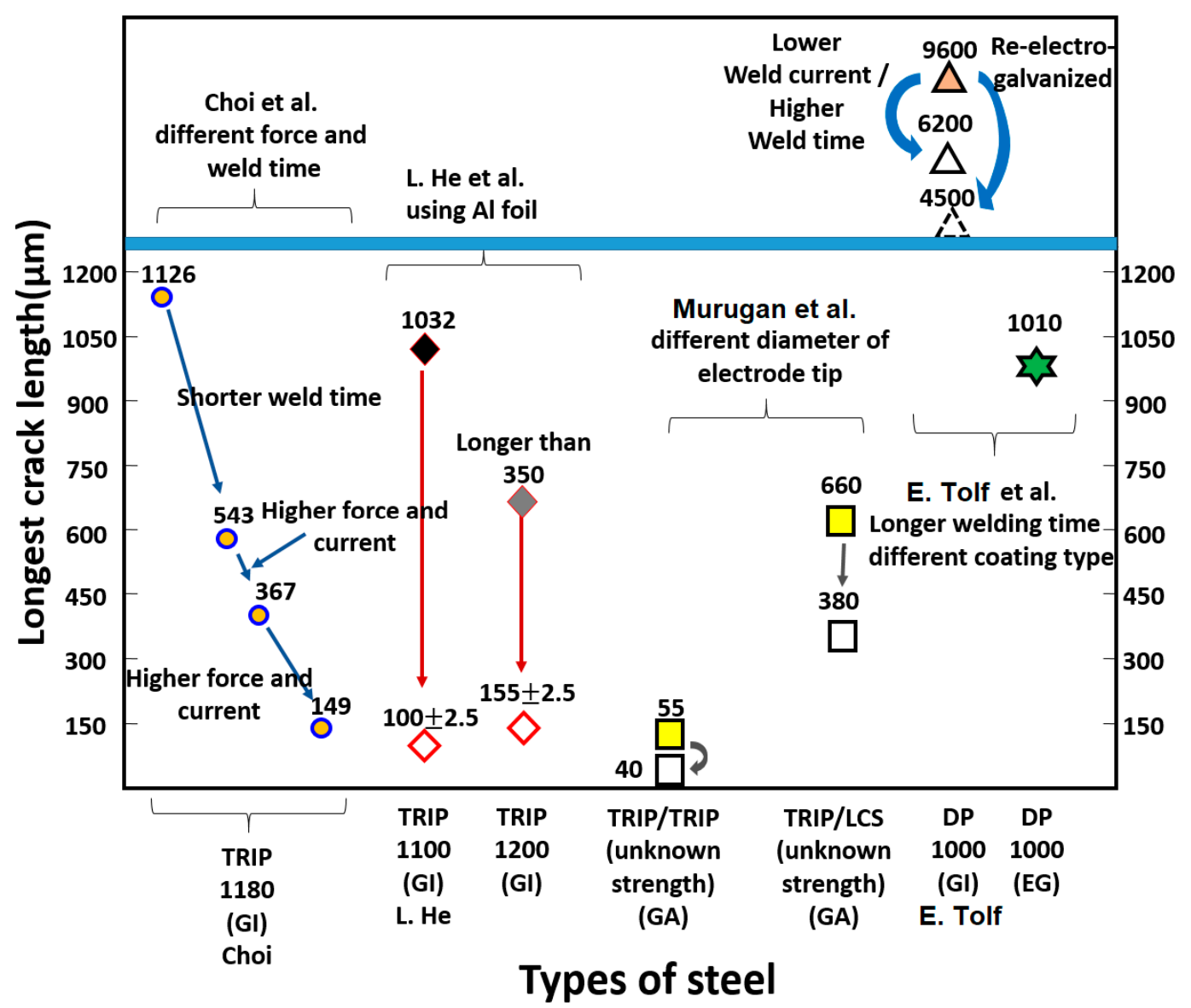

Figure 9. Studies about decreasing LME cracks on several types of TRIP and Dual-Phase (DP) steels.

Choi et al. studied the relationship between electrode force and LME crack length of TRIP 1180. A $3 \mathrm{kN}$ forced sample showed a longer crack length $(1282 \mu \mathrm{m})$ compared to the $5 \mathrm{kN}$ forced workpiece [36,97]. A finite element method revealed that, if a weaker electrode force was applied, the adjacent area between electrode and steel was reduced and the cooling effect decreased. Therefore, the temperature of the steel surface is maintained at over $600^{\circ} \mathrm{C}$ for a longer time, which is enough for the propagation of $\mathrm{Zn}$ metal. It can be noted that the longest crack length is decreased $(1126 \mu \mathrm{m}$ to $149 \mu \mathrm{m}$ ) with an increasing force. A decrease in crack length was also observed by other researchers. He et al. used $25 \mu \mathrm{m}$ thick $\mathrm{Al}$ foil to suppress the crack growth. Al foil was placed between the $\mathrm{Zn}$-coated steel and counter electrode surfaces [97,98]. Iron aluminides ( $\mathrm{FeAl}, \mathrm{FeAl}_{2}, \mathrm{Fe}_{2} \mathrm{Al}_{5}$ ) were formed at the indented area, and it was reported that iron aluminides need smaller formation energies than iron-zinc intermetallic compounds [98]. Therefore, an iron aluminides inhibition layer was created between $\mathrm{Zn}$ and the steel surface and hindered liquid zinc from propagating the steel surface. Murugan et al. investigated the influence of electrode geometry on LME cracks [25,72]. Crack length decreased from 55 to $40 \mu \mathrm{m}$ when the diameter of the dome-type electrode increased from 6 to $8 \mathrm{~mm}$. A $7.2 \mathrm{~mm}$ nugget diameter sample showed a dramatic decrease in the size and number of LME cracks when the radius-type electrode was used instead of dome-type one. Tolf et al. discovered that length of the LME cracks reduced when a lower weld current $(8.0 \mathrm{kA}$ to $6.5 \mathrm{kA})$ and a longer weld time ( $410 \mathrm{~ms}$ to $615 \mathrm{~ms}$ ) were applied during the RSW of DP steel [70]. It was also found that re-electro galvanization of GI-coated steel showed a significantly decreased number of cracks. The EG-coated steel consistently showed the shortest LME cracks. These results show that the LME susceptibility of GI is greater than EG, which is consistent with the results of the previous works $[23,36,43,44,74,76]$. 


\subsubsection{Effect of Electrode Force on LME}

In some studies, it was found that the lower electrode force caused severe LME [35,36]. For instance, Figure 10 presents the temperature and stress profile of the indented area. This area is seen in region III, node 583. It was revealed that the longest LME crack was found at F3W4 ( $3 \mathrm{kN}$ electrode force and $400 \mathrm{~ms}$ weld time), compared to F4W4 or F5W4. It can be seen that peak temperature was highest (green line, $1120^{\circ} \mathrm{C}$ ) at the F3W4 condition in Figure 10a.

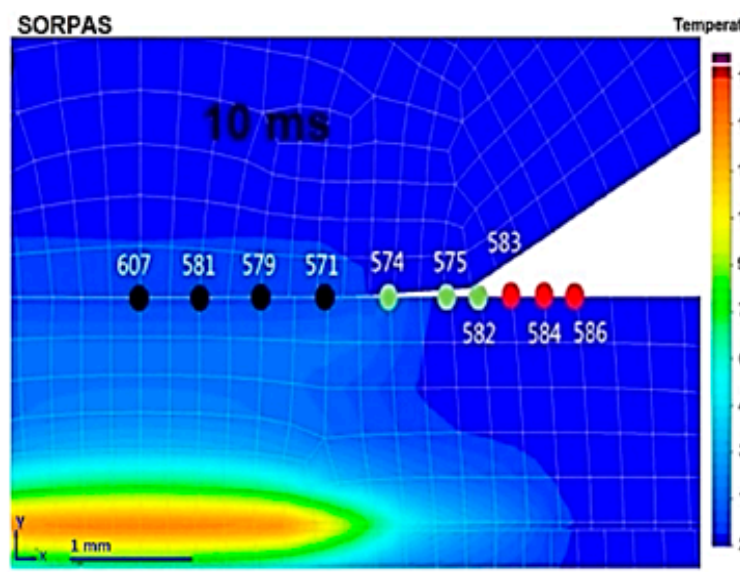

(a)

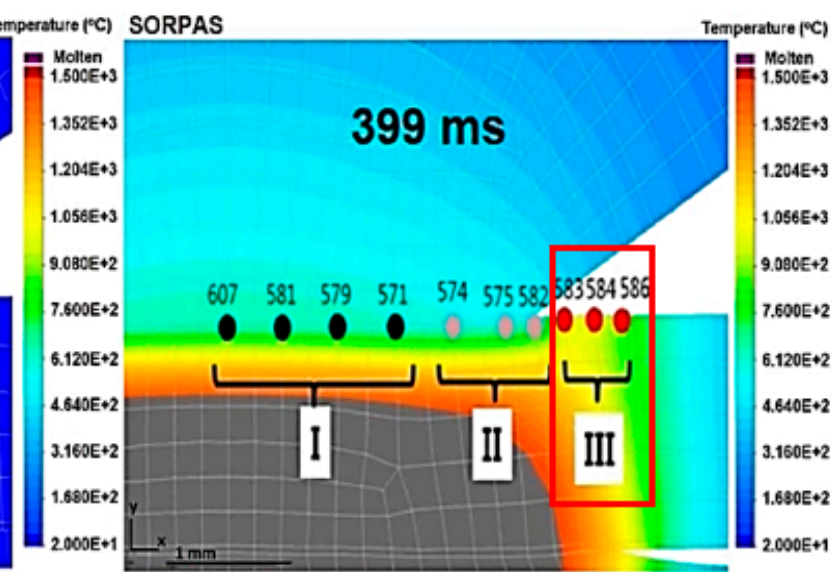

(b)

Figure 10. (a) An LME crack simulation of electrode-workpiece interaction. (b) Temperature profile and stress distribution across different regions. Node 583 is estimated to have the longest LME cracks because a high tensile stress and a high temperature of about $900{ }^{\circ} \mathrm{C}$ were maintained for $200-600 \mathrm{~ms}$. Reprinted with permission from [36], Springer, 2018.

Due to the lowest force, the lowest tensile stress was obtained at F3W4. The reason for severe LME cracks was attributed to the lower electrode force, which delayed the contact time to the workpiece and decreased the cooling effect of the electrode. Therefore, the exposure time of liquid $\mathrm{Zn}$ increased the penetration of the steel surface as shown in Figure 11a,b.

(a)

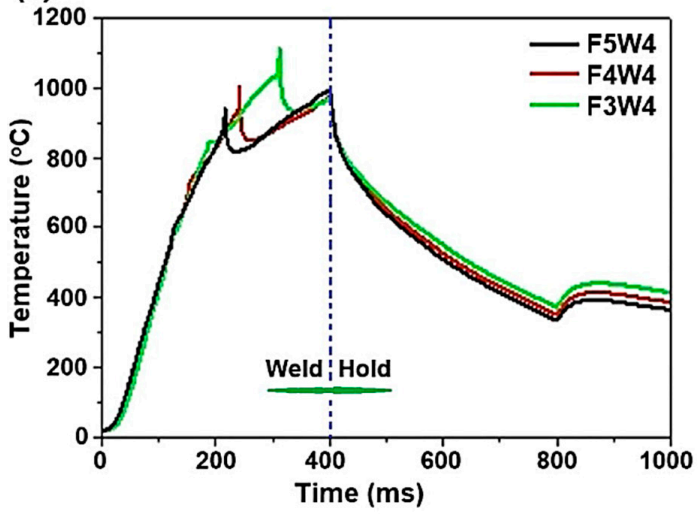

(b)

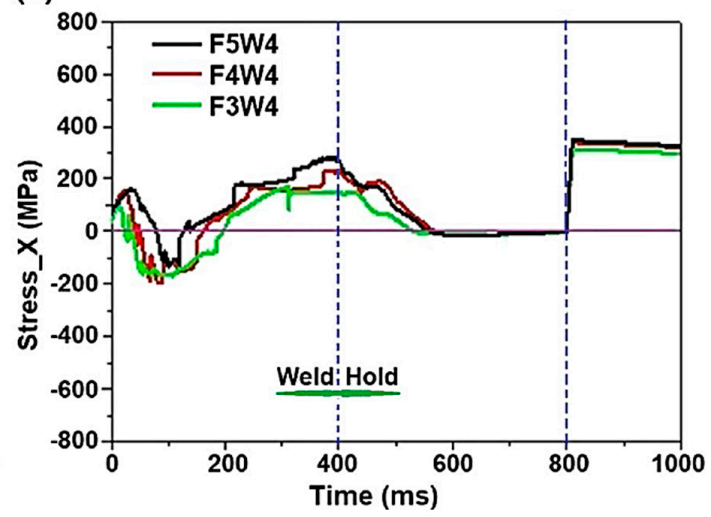

Figure 11. A comparison of (a) temperature profile and (b) stress history across various welding conditions at node 583 location. Reprinted with permission from [36], Springer, 2018.

These results contradict the previous work where applying higher electrode force easily leads to severe surface expulsion causing a higher probability of LME cracks [37]. However, a lower electrode force and weld current than the expulsion occurring range is a prerequisite, according to several LME studies. Kim et al. also found that the surface cracking ratio was increased as the electrode force decreased [36-39]. They explained that a lower electrode force increased the contact resistance and led 
to a higher probability of LME cracks. This result is also consistent with Wu's work [69]. Because of the cooling effect and low contact resistance, it is advantageous to apply a high electrode force to reduce crack sensitivity.

\subsubsection{Effect of Electrode Geometry on LME Reduction}

Another critical factor that affects the LME severity is electrode geometry. The main roles of the electrode are as follows: (1) to apply a welding current to the steel sheet without Joule's heating dissipation, (2) to reduce heat from the workpiece and control weld nugget creation, (3) to apply a concentrated force/pressure on the workpiece [72,76].

Barthelme et al. revealed that an increase in cap diameter reduced the average LME crack length down to 50\%; however, even a larger cap could not prevent all the cracks [73]. Sierlinger investigated the effect of electrode geometry and reported that larger cap could reduce LME, but not entirely [29]. However, it is uncertain whether heat input is always the same in these studies because there exists a different "critical nugget diameter" for each type of coating [73]. Di Giovanni analyzed the impact of electrode geometry which created similar nugget sizes [25,72,99-101]. This study only treated GI steels; therefore, further investigations related to different galvanized steel types are also required. Di Giovanni's study indicated that the radius-type electrode further reduced LME cracks compared to the B-nose and truncated-cone-type electrodes. This result was also consistent with Murugan's works $[25,72,101]$. Murugan et al. revealed that the radius-type electrode reduced LME cracks compared to the dome-type electrode [25,72]. It was explained that the radius-type electrode showed less geometric singularity and a higher contact area between the electrode and surface. This resulted in a decreased temperature and lower tensile stress. Figure 12 exhibits the temperature profiles of different electrode types. It shows that the radius-type electrode (Figure $12 \mathrm{~b}, \mathrm{~d}$ ) resulted in lower peak temperatures compared to dome-type at the electrode-surface interface. It is also notable that the peak temperature at the edge part of indentation (Figure 12c,d) is always higher than the center part (Figure 12a,b). Also, it is presented that the contact area between interfaces of the radius-type electrode is much larger than the dome-type electrode. This increases the cooling effect that reduces the existence time of liquid $\mathrm{Zn}$.

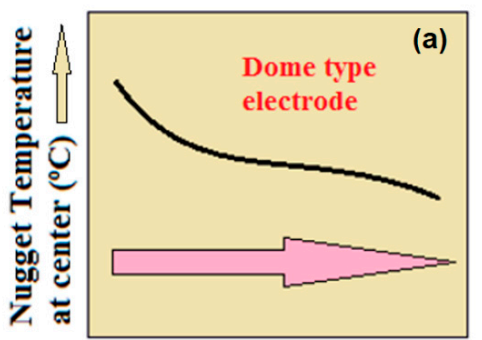

Tip diameter $(\mathbf{m m})$

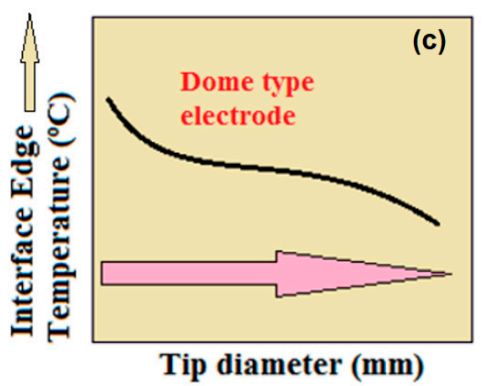

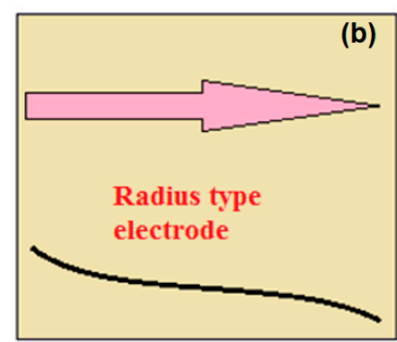
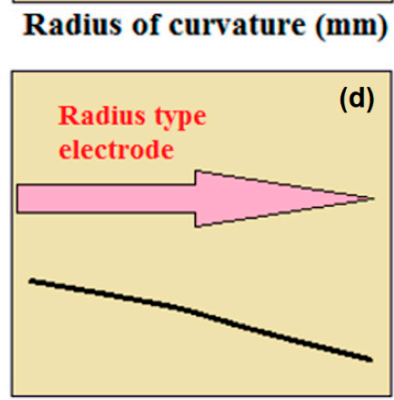

Radius of curvature (mm)

Figure 12. Temperature at the electrode-surface interface: (a) temperature at the center part (nugget) with a diameter of dome electrode; (b) temperature at the center with radius-type electrode; (c) temperature at the edge with a diameter of dome electrode; and (d) temperature at the edge with radius-type electrode. 


\subsection{Evaluation of LME Crack on TRIP Steel}

Some studies have investigated the LME susceptibility of AHSSs through a hot tensile test [96,100]. Beal et al. revealed that applying tensile stress to EG coated steel after holding at $750{ }^{\circ} \mathrm{C}$ for $30 \mathrm{~s}$ exhibited the almost same behavior as the bare one [96]. Figure 13 represents the tensile curves obtained at $750{ }^{\circ} \mathrm{C}$ for different holding times. It shows that the observed $\mathrm{Zn}-\mathrm{Fe}-\mathrm{Mn}$ intermetallic compounds (not pure $\mathrm{Zn}$ ) near the fracture region are responsible for the recovery of ductility. The exposure period to liquid $\mathrm{Zn}$ decreased with increased holding time.

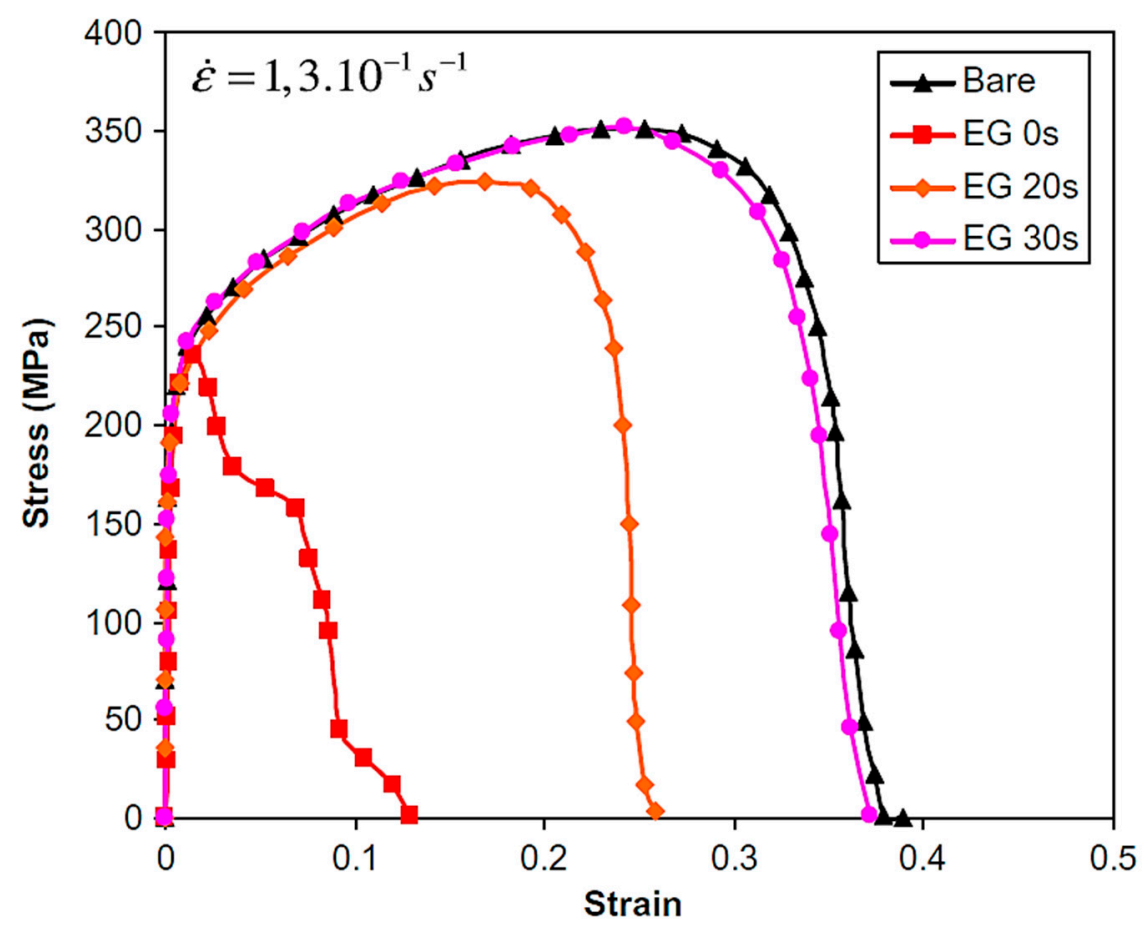

Figure 13. Tensile curves obtained at $750{ }^{\circ} \mathrm{C}$ (strain rate $\left.0.13 \mathrm{~s}^{-1}\right)$ : progressive ductility recovery after holding at $750{ }^{\circ} \mathrm{C}$. Reprinted from [96] with permission of Elsevier, 2012.

Due to the LME cracks, a severe reduction in the lap shear strength of GI TRIP 1100 was noticed [36,96]. It was explained that large LME cracks $(>400 \mu \mathrm{m})$ on TRIP 1100 propagated along a fracture path [101]. The smaller cracks $(<100 \mu \mathrm{m})$ in TRIP $690 \mathrm{did}$ not play a significant role in severe loss of strength. Figure 14 presents $43.6 \%$ decreased lap shear strength in coated GI TRIP steel. It is noteworthy that significant strength reduction, as well as larger LME cracks, occurred on TRIP 1100. Therefore, further research related to the acceptable crack length is required.

However, these results contradict the following findings related to the investigations related to the fatigue life and LME [35,102]. Kim et al. conducted a high-cycle fatigue test in a tensile mode [35]. The effect of crack length was compared between two welded GA 590 TRIP steel samples. The weld current was 8.4 and $12.0 \mathrm{kA}$, respectively, and severe cracks (about $1 \mathrm{~mm}$ in Figure 15) were produced at $12.0 \mathrm{kA}$. Figure 15 presents the fatigue test conditions. The fatigue test was stopped when more than $0.3 \mathrm{~mm}$ displacement remained. In all cases $(3.7-4.0 \mathrm{kN})$, the fatigue life of $12 \mathrm{kA}$ samples was longer than that of $8.4 \mathrm{kA}$ samples. The fatigue fracture started the interface of TRIP steel and propagated to the end of the concave side. It was concluded that tensile fatigue life depends on the size of weld nugget rather than the surface LME crack. 


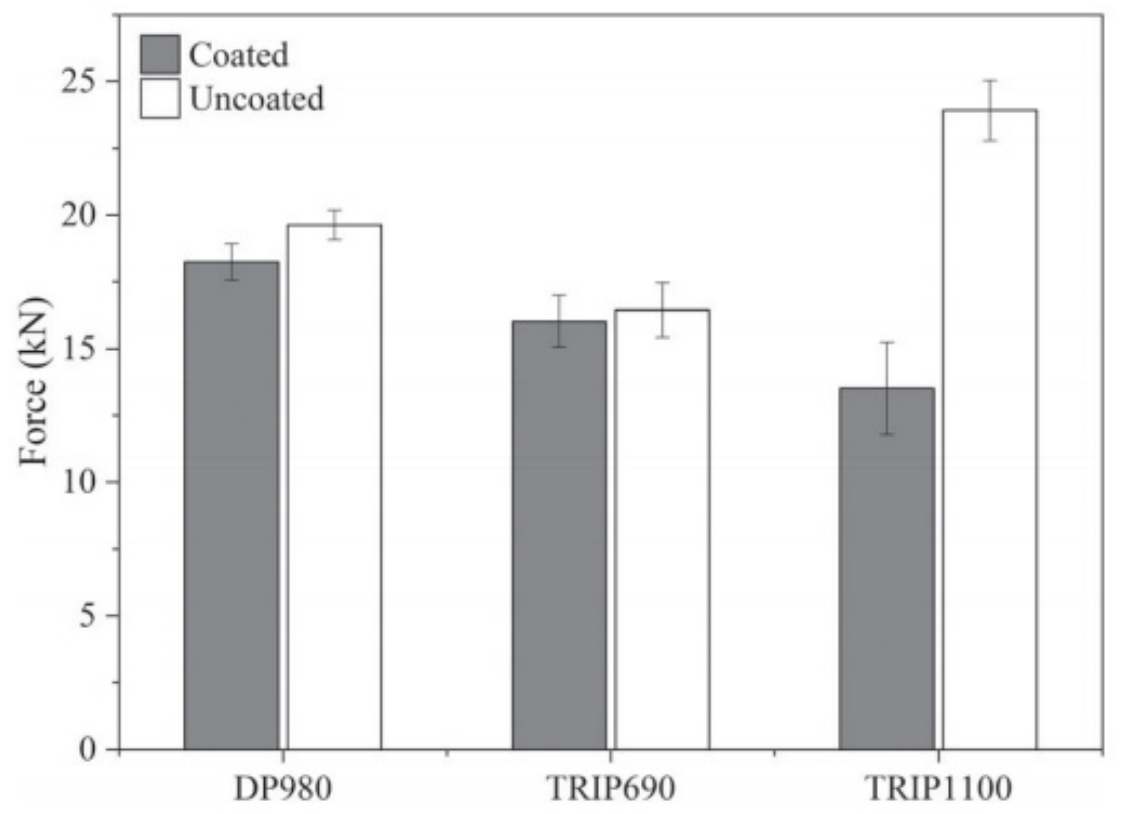

Figure 14. Mean lap shear strength for each material, coated and uncoated. Reprinted from [101], with permission of Taylor and Francis, 2019, http://www.tandfonline.com.
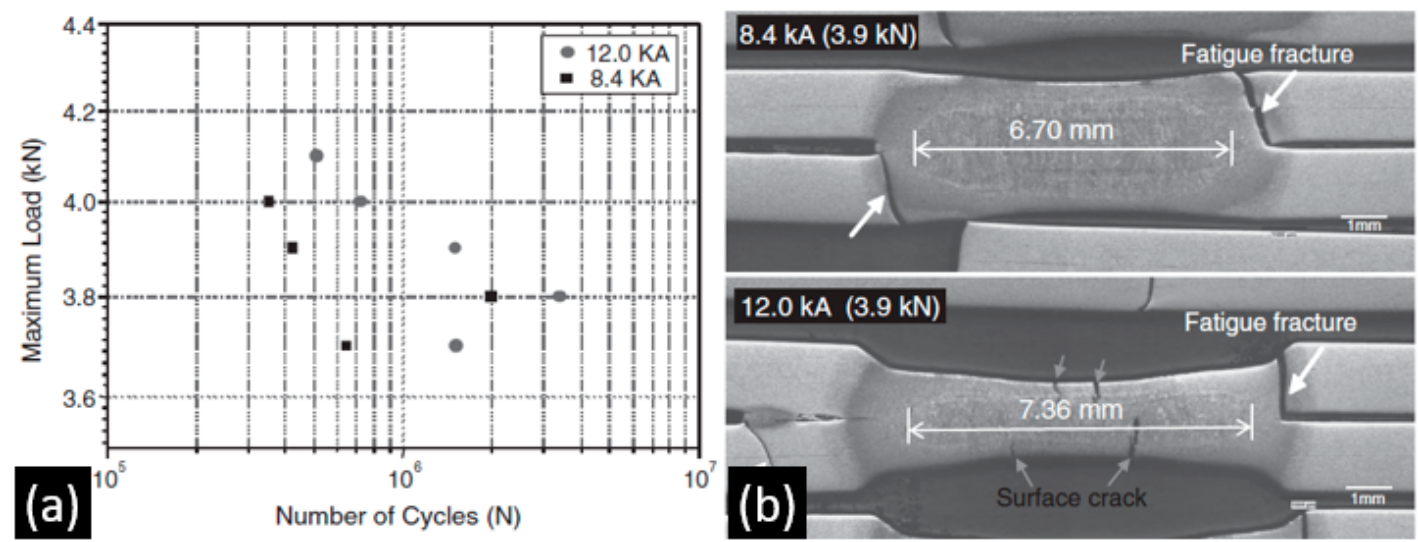

Figure 15. (a) Fatigue conditions; (b) fatigue fractures of $8.4 \mathrm{kA}$, and $12.0 \mathrm{kA}$ current welded 590 TRIP steel. The weld nugget diameters are 6.7 and $7.36 \mathrm{~mm}$, respectively. In all cases of fatigue test, the $12.0 \mathrm{kA}$ sample (gray dot in Figure (a)) showed a longer fatigue life (black dot in Figure (b)). Reprinted from [35], with permission of the Japan Institute of Metals, JIM, 2014.

Gaul et al. also investigated the influence of heat-affected zone (HAZ) cracks on the fatigue strength of GI TRIP 700 steel [102]. No visible reduction in fatigue life and stiffness was observed. Furthermore, cracks derived from fatigue test even grew in a parallel direction to the original HAZ crack on the steel surface, as shown in Figure 16. Therefore, it was concluded that the fatigue life was not seriously decreased by HAZ cracks in the indented area. It can be inferred that the effects of crack length on lap shear strength and fatigue life need more detailed examination. 
a)

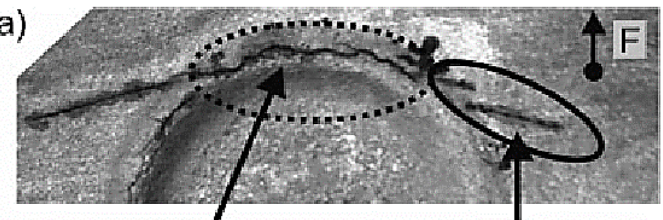

$\mathrm{HAZ}$ crack

Fatigue crack

b)
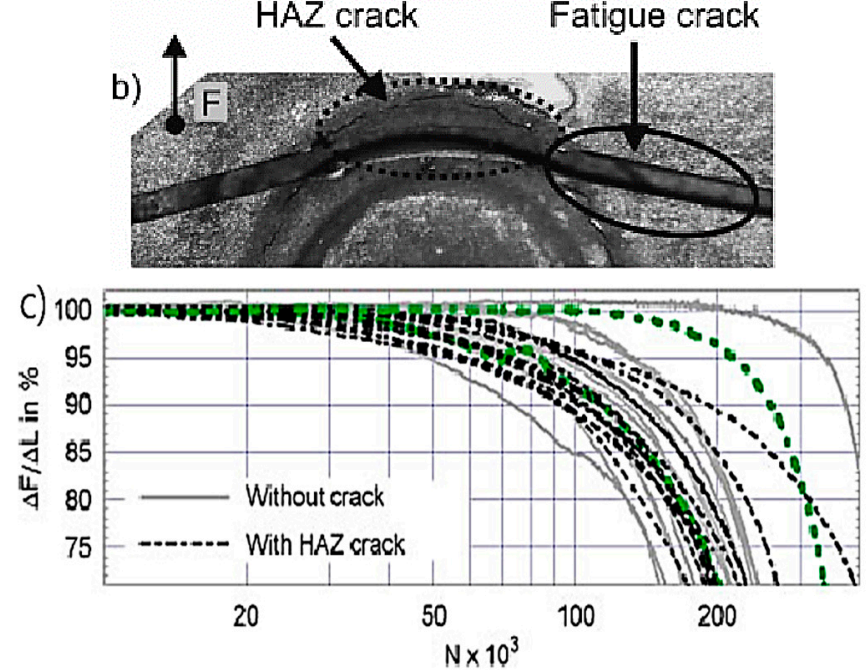

Figure 16. Influence of HAZ crack on fatigue life of resistance spot welded GI TRIP 700 steel. $(\mathbf{a}, \mathbf{b})$ Direction of fatigue force depicted as arrowed " $\mathrm{F}$ ", (c) stiffness characteristics of crack-free (solid line), HAZ cracked (black dotted line), crack combined (light black dotted line). Reprinted from [102], with permission of Taylor and Francis, 2011, http://www.tandfonline.com.

\section{Future Guidelines and Prospects}

(1) A detailed analysis of the cracks propagated through TRIP steel is required. In the case of TWIP steel, there exists a phase investigation of cracks [35]. It was seen that the $\mathrm{Fe}_{2} \mathrm{Al}_{5}$ layer was deformed by the created $\alpha$-Fe particles with $30 \mathrm{wt} \%$ of $\mathrm{Zn}$. The crack area was composed of $\Gamma\left(\mathrm{Fe}_{3} \mathrm{Zn}_{11}\right)$. Meanwhile, there are not enough studies of LME issues in detail. A crack analysis should be preceded in detail to figure out the cause of LME.

(2) Understanding the influence of different types of coating is required. Until now, the exact comparison of the GI, GA, EG coating effects to LME has not yet been conducted. Each coating has unique intermetallic behavior before and after melting. As referred to in this study, the intermetallic compounds phase could appear after the coating melts, and this could cause more LME cracks.

(3) A detailed crack evaluation is required. In other words, LME cracks are located in various places of welds and exist in different lengths. The influence of all situations has not been fully considered in the literature. Until now, only a few studies have investigated issues of LME cracks and fatigue life. From these studies, it is concluded that LME cracks have no visible effect on fatigue life $[102,103]$. However, the reported shear lap strength also noticeably decreased. Therefore, fatigue reliability and strength should be analyzed for several types of cracks. Besides, the minimum length of cracks which degrade fatigue life should also be investigated.

(4) The use of advanced nanoparticle-reinforced fillers can be introduced to control crack propagation and growth. Some composite fillers have been used in the micro-joining of aluminum parts $[104,105]$. Although there is not enough literature on this area yet, it might be promising to control the LME cracks induced by the zinc metal.

\section{Conclusions}

In this study, we focused on an overview of liquid metal embrittlement of the galvanized TRIP steel. In particular, the cause of LME was analyzed concerning the surface tension of $\mathrm{Zn}$ and the 
grain boundary of steel. TRIP steel shows outstanding elongation and high formability. However, the commercialization of the TRIP steel autobody is delayed due to various LME issues.

There are several investigations into the LME of resistance spot-welded AHSSs. However, most of them focus on switching welding parameters, such as electrode force, weld current, weld time, electrode geometry, etc. It takes great effort to find suitable welding conditions for every new steel grade. Therefore, a new aspect to figure out the fundamental suppression of LME is required.

Though new materials, such as carbon fiber reinforced plastic (CFRP) and lightweight aluminum, have arisen as a replacement for steel in vehicles, the product cost and reliability problems have not been solved. Therefore, it is also urgent to establish a standard regarding permissible crack length at diverse tensile and fatigue conditions.

Author Contributions: Conceptualization and methodology, W.-S.J.; formal analysis and validation, A.S.; resources and supervision, J.P.J.; writing-original draft preparation, W.-S.J.; writing—review and editing, J.P.J. All authors have read and agreed to the published version of the manuscript.

Funding: This research received no external funding.

Conflicts of Interest: The authors declare no conflict of interest.

\section{References}

1. Galan, J.; Samek, L.; Verleysen, P.; Verbeken, K.; Houbaert, Y. Advanced high strength steels for automotive industry. Rev. Metal. 2012, 48, 118-131. [CrossRef]

2. Keeler, S.; Kimchi, M. Advanced High-Strength Steels Application Guidelines, Version 5.0; WorldAutoSteel: Brussels, Belgium, 2015.

3. Han, T.K.; Lee, K.Y.; Kim, J.S. Recent developments and weldability of advanced high strength steels for automotive applications. JWJ 2009, 27, 13-18.

4. April 2020 Crude Steel Production. Available online: https://www.worldsteel.org/media-centre/pressreleases/2020/April-2020-crude-steel-production.html (accessed on 6 June 2020).

5. Advanced High-strength Steel Market by Grade (Dual Phase, Transformation-Induced Plasticity, Complex Phase, and Others) and End User (Automotive, Construction, and Others)—Global Opportunity Analysis and Industry Forecast, 2017-2023. Available online: https://www.alliedmarketresearch.com/advanced-highstrength-steel-market (accessed on 6 June 2020).

6. Thomas, G.; Koo, J.Y. Structure and Properties of Dual Phase Steels. In AIME Symposium; Kott, R.A., Morris, J.W., Eds.; Metallurgical Society of AIME: Englewood, CO, USA, 1979; p. 183.

7. Jiang, Z.; Guan, Z.; Lian, J. Effects of microstructural variables on the deformation behaviour of dual-phase steel. Mater. Sci. Eng. A 1995, 190, 55-64. [CrossRef]

8. Bag, A.; Ray, K.K.; Dwarakadasa, E.S. Influence of martensite content and morphology of tensile and impact properties of high-martensite dual-phase steels. Metall. Mater. Trans. A 1990, 30, 1193-1202. [CrossRef]

9. Meng, Q.; Li, J.; Wang, J.; Zhang, Z.; Zhang, L. Effect of water quenching process on microstructure and tensile properties of low alloy cold rolled dual-phase steel. Mater Des. 2009, 30, 2379-2385. [CrossRef]

10. Srivastava, A.K.; Patel, N.K.; Kumar, B.R.; Sharma, A.; Ahn, B. Strength-ductility trade-off in dual-phase steel tailored via controlled phase transformation. J. Mater. Eng. Perform. 2020, in press. [CrossRef]

11. Fonstein, N. Advanced High Strength Sheet Steels, 1st ed.; Springer: Cham, Switzerland, 2015.

12. Jeanneau, M.; Pichant, P. The trends of steel products in the European automotive industry. Rev. Métallurgie 2000, 97, 1399-1408. [CrossRef]

13. Matsumura, O.; Sakuma, Y.; Takechi, H. Enhancement of elongation by retained austenite in intercritical annealed 0.4C-1.5Si-O.8Mn Steel. Scr. Metall. 1987, 21, 301-1306.

14. Matsumura, O.; Sakuma, Y.; Takechi, H. Mechanical properties and retained Austenite in intercritically heat treated bainite-transformed steel and their variations with Si and Mn additions. Metall. Trans. A 1991, 22A, 489-498.

15. Cooman, B.C.D. Structure-properties relationship in TRIP steels containing carbide-free bainite. Curr. Opin. Solid St. Mater. Sci. 2004, 8, 285-303. [CrossRef]

16. Cooman, B.C.D.; Kwon, O.; Chin, K.G. State-of-the-knowledge on TWIP steel. Mater. Sci. Technol. 2012, 28, 513-527. [CrossRef] 
17. Horvath, C.D. Materials, Design and Manufacturing for Lightweight Vehicles. In Woodhead Publishing Series in Composites Science and Engineering; Mallick, P.K., Ed.; Woodhead Publishing: Cambridge, UK, 2010; pp. 35-78.

18. Chung, P.P.; Wang, J.; Durandet, Y. Deposition processes and properties of coatings on steel fasteners-A review. Friction 2019, 7, 389-416. [CrossRef]

19. Townsend, H.E.; Allegra, L.; Dutton, R.J.; Kriner, S.A. Hot-dip coated sheet steels-a review. Mater. Perform. 1986, 25, 36-46.

20. Dionne, S. The characterization of continuous hot-dip galvanized and galvannealed steels. JOM 2006, 58, 32-40. [CrossRef]

21. Shome, M.; Tumuluru, M. Welding and Joining of Advanced High Strength Steels (AHSS); Woodhead Publication Series in Welding and Other Joining Series 85; Woodhead Publishing: Cambridge, UK, 2015.

22. Lynch, S.P. Stress Corrosion Cracking. In Woodhead Publishing Series in Metals and Surface Engineering; Raja, V.S., Shoji, T., Eds.; Woodhead Publishing: Cambridge, UK, 2011.

23. Ashiri, R.; Shamanian, M.; Salimijazi, H.R.; Haque, M.A.; Bae, J.H.; Ji, C.W.; Chin, K.G.; Park, Y.D. Liquid metal embrittlement-free welds of Zn-coated twinning induced plasticity steels. Scr. Mater. 2016, 114, 41-47. [CrossRef]

24. Yi, H.L.; Lee, K.Y.; Kim, J.H.; Bhadesia, H.K.D.H. Spot weldability of $\delta$-TRIP steel containing $0 \cdot 4$ wt-\%C. Sci. Technol. Weld. Join. 2010, 15, 619. [CrossRef]

25. Murugan, S.P.; Cheepu, M.; Vijayan, V.; Ji, C.; Park, Y.D. The resistance spot weldability of a stainless steel/aluminium/low carbon steel 3-ply clad sheet. JWJ 2018, 36, 25-33. [CrossRef]

26. Kim, D.C.; Jo, H.G.; Kim, Y.M.; Kang, M.J.; Hwang, I. Effects of electrode face thickness on resistance spot weldability of aluminium alloy 6061. JWJ 2020, 38, 67-72. [CrossRef]

27. Lee, J.J.; Son, C.S.; Park, Y.W. Resistance spot welding characteristic of 1500MPa steel sheet using simulation (II) -Estimation model for nugget diameter of resistance spot welds. JWJ 2018, 36, 51-56. [CrossRef]

28. Choi, S.G.; Hwang, I.; Kang, M.; Hyun, S.; Kim, Y.M. Optimization of welding parameters in resistance spot welding of $980 \mathrm{MPa}$ grade GA steel sheet using multi-response surface methodology. JWJ 2018, 36, 63-69. [CrossRef]

29. Sierlinger, R.; Gruber, M. A Cracking Good Story about Liquid Metal Embrittlement During Spot Welding of Advanced High Strength Steels; White Paper; Voestalpine Stahl GmbH, Voestalpine-Strabe: Linz, Austria, 2016; pp. 1-16.

30. Li, Y.; Ma, Y.; Lou, M.; Lei, H.; Lin, Z. Advances in Welding and Joining Processes of Multi-material Lightweight Car Body. J. Mech. Eng. 2016, 52, 1-23. (In Chinese) [CrossRef]

31. Cho, G. The Automotive Industry: Core Research from Industry; Abington Publishing, Woodhead Publishing Limited: Cambridge, UK, 2000.

32. Klinger, J.F. Automotive Body Structure Assembly, Mass and Cost Saving Potential of Laser Welding Compared to Spot Welding. Master's Thesis, KTH Royal Institute of Technology, Stockholm, Sweden, 2012.

33. Bhattacharya, D. Liquid metal embrittlement during resistance spot welding of Zn-coated high-strength steels. Mater. Sci. Technol. 2018, 34, 1809-1829. [CrossRef]

34. Kim, S.J.; Jeong, H. Development of structural steel and trend of welding technology. JWJ 2016, 34, 7-20.

35. Kim, Y.G.; Kim, I.J.; Kim, J.S.; Chung, Y.I.; Choi, D.Y. Evaluation of Surface Crack in Resistance Spot Welds of Zn-Coated Steel. Mater. Trans. 2014, 55, 171-175. [CrossRef]

36. Choi, D.Y.; Sharma, A.; Uhm, S.H.; Jung, J.P. Liquid metal embrittlement of resistance spot welded 1180 TRIP steel: Effect of electrode force on cracking behavior. Met. Mater. Int. 2018, 25, 219-228. [CrossRef]

37. Zhou, K.; Cai, L. Study on effect of electrode force on resistance spot welding process. J. Appl. Phys. 2014, 116, 084902. [CrossRef]

38. Jo, H.G.; Kim, Y.M.; Kang, M.J.; Kim, D.C. Effects of electrode face radius and force on resistance spot weldability of aluminium Alloy 6061. JWJ 2018, 36, 46-51. [CrossRef]

39. Jo, B.J.; Kim, J.S.; Yoo, H.S.; Kim, I.J.; Lee, S.H.; Kim, Y.G. Characterization of resistance spot welded Al5052/DP590 dissimilar materials and processing optimization. JWJ 2015, 33, 56-61.

40. Emre, H.E.; Kacar, R. Resistance spot weldability of galvanize coated and uncoated TRIP steels. Metals 2016, 6, 299. [CrossRef]

41. Digiovanni, C.; Han, X.; Powell, A.; Biro, E.; Zhou, N.Y. Experimental and numerical analysis of liquid metal embrittlement crack location. J. Mater. Eng. Perform. 2019, 28, 2045-2052. [CrossRef] 
42. Wintjes, E.; Digiovanni, C.; He, L.; Biro, E.; Zhou, Y.N. Quantifying the link between crack distribution and resistance spot weld strength reduction in liquid metal embrittlement susceptible steels. Weld. World 2019, 63, 807-814. [CrossRef]

43. Ashiri, R.; Marashi, S.P.H.; Park, Y.D. Weld processing and mechanical responses of 1-GPa TRIP steel resistance spot welds. Weld. J. 2018, 97, 157-169.

44. Ashiri, R.; Mostaan, H.; Park, Y.D. A phenomenological study of weld discontinuities and defects in resistance spot welding of advanced high strength TRIP steel. Metall. Mater. Trans. A 2018, 49, 6161-6172. [CrossRef]

45. Kim, Y.H.; Kim, Y.G.; Kim, D.C.; Joo, S.M. Optimization of weld-bonding process conditions of dissimilar materials using delta spot welding. JWJ 2019, 37, 231-236. [CrossRef]

46. Béres, G.; Tisza, M. Vehicle and Automotive Engineering. In Lecture Notes in Mechanical Engineering; Jármai, K., Bolló, B., Eds.; Springer: Cham, Switzerland, 2017; p. 204.

47. Choi, J.H.; Jo, M.C.; Lee, H.S.; Zargaran, A.; Song, T.; Sohn, S.S.; Kim, N.J.; Lee, S. Cu addition effects on TRIP to TWIP transition and tensile property improvement of ultra-high-strength austenitic high-Mn steels. Acta Mater. 2019, 166, 246-260. [CrossRef]

48. Papatriantafillou, I.; Agoras, M.; Aravas, N.; Haidemenopoulos, G.N. Constitutive modeling and finite element methods for TRIP steels. Comput. Methods Appl. Mech. Eng. 2006, 195, 5094-5114. [CrossRef]

49. Maki, J.; Mahieu, J.; Cooman, B.C.D.; Claessens, S. Galvanisability of silicon free CMnAl TRIP steels. Mater. Sci. Technol. 2003, 19, 125-131. [CrossRef]

50. Wang, X.D.; Huang, B.X.; Rong, Y.H.; Wang, L. Microstructures and stability of retained austenite in TRIP steels. Mater. Sci. Eng. A 2006, 438-440, 300-305. [CrossRef]

51. Hao, Q.; Qin, S.; Liu, Y.; Zuo, X.; Chen, N.; Huang, W.; Rong, Y. Effect of retained austenite on the dynamic tensile behavior of a novel quenching-partitioning-tempering martensitic steel. Mater. Sci. Eng. A 2016, 662, 16-25. [CrossRef]

52. Park, S.S.; Choi, Y.M.; Nam, D.G.; Kim, Y.S.; Yu, J.H.; Park, Y.D. Evaluation of resistance spot weld interfacial fractures in tensile-shear tests of TRIP 1180 steels. JWJ 2009, 26, 81-91.

53. Lee, J.D.; Lee, S.J.; Bang, J.H.; Yoon, G.S.; Kim, M.S.; Kim, J.K. Weld quality evaluation method for the resistance spot welds using X-ray transmission inspection. JWJ 2014, 32, 537-543.

54. Herrera, C.; Ponge, D.; Raabe, D. Design of a novel Mn-based 1 GPa duplex stainless TRIP steel with $60 \%$ ductility by a reduction of austenite stability. Acta Mater. 2011, 59, 4653-4664. [CrossRef]

55. Blumenau, M.; Norden, M.; Friedel, F.; Peters, K. Galvannealing of (high-) manganese-alloyed TRIP-and X-IP ${ }^{\circledR}$-steel. Steel Res. Int. 2010, 81, 1125-1136. [CrossRef]

56. Meyer, M.D.; Wit, K.D.; Cooman, B.D. The bake hardening behavior of electro-galvanized cold rolled CMnSi and CMnAlSi TRIP steel. Steel Res. 2000, 71, 511-518. [CrossRef]

57. Bellhouse, E.M.; Mertens, A.I.M.; McDermid, J.R. Development of the surface structure of TRIP steels prior to hot-dip galvanizing. Mater. Sci. Eng. A 2007, 463, 147-156. [CrossRef]

58. Jacques, P.J.; Girault, E.; Mertens, A.; Verlinden, B.; Humbeeck, J.V.; Delannay, F. The developments of cold-rolled TRIP-assisted multiphase steels. Al-alloyed TRIP-assisted multiphase steels. ISIJ Int. 2001, 41, 1068-1074. [CrossRef]

59. Mahieu, J.; Cooman, B.C.D.; Claessens, S. Galvanizability of high-strength steels for automotive applications. Metall. Mater. Trans. A 2001, 32, 2905-2908. [CrossRef]

60. Bellhouse, E.M.; Mcdermid, J.R. Selective oxidation and reactive wetting during hot-dip galvanizing of a 1.0\% Al-0.5\% Si TRIP-assisted steel. Metall. Mater. Trans. A 2012, 43, 2426-2441. [CrossRef]

61. Oh, J.H.; Cho, L.; Kim, M.; Kang, K.; Cooman, B.C.D. The effect of Bi on the selective oxide formation on CMnSi TRIP steel. Metall. Mater. Trans. A 2016, 47, 5474-5486. [CrossRef]

62. Wang, K.K.; Hsu, C.W.; Chang, L.; Gan, D.; Yang, K.C. Role of Al in Zn bath on the formation of the inhibition layer during hot-dip galvanizing for a $1.2 \mathrm{Si}-1.5 \mathrm{Mn}$ transformation-induced plasticity steel. Appl. Surf. Sci. 2013, 285, 458-468. [CrossRef]

63. Cho, L.; Kim, M.S.; Kim, Y.H.; Cooman, B.C.D. Influence of gas atmosphere dew point on the galvannealing of CMnSi TRIP steel. Metall. Mater. Trans. A 2013, 44, 5081-5095. [CrossRef]

64. Son, J.W.; Nam, D.G.; Kim, D.C.; Park, Y.D. Effect of paint baking on the strength and failure of spot welds for 780 TRIP steels. JWJ 2010, 28, 66-73. [CrossRef]

65. Oikawa, H.; Murayama, G.; Hiwatashi, S.; Matsuyama, K. Resistance spot weldability of high strength steel sheets for automobiles and the quality assurance of joints. Weld. World 2007, 51,7-18. [CrossRef] 
66. Wintjes, E.; Digiovanni, C.; He, L.; Bag, S.; Goodwin, F.; Biro, E.; Zhou, Y. Effect of multiple pulse resistance spot welding schedules on liquid metal embrittlement severity. J. Manuf. Sci. Eng. 2010, 141, 101001. [CrossRef]

67. Galler, M.; Enzinger, N.; Sommitsch, C. The estimation of the contact interface temperature during resistance spot welding of zinc coated steels using numerical technique. Mater. Sci. Eng. Technol. 2010, 41, 925-930.

68. Huda, N.; Nam, D.G.; Park, Y.D. Study on the mechanism of nugget growth behavior in three sheets stack resistance spot welding. JWJ 2019, 37, 564-571. [CrossRef]

69. Wu, K.C. Resistance spot welding of high contact-resistance surfaces for weldbonding. Welding J. Res. Suppl. 1975, 54, 436s-443s.

70. Tolf, E.; Hedegard, J.; Melander, A. Surface breaking cracks in resistance spot welds of dual phase steels with electrogalvanised and hot dip zinc coating. Sci. Technol. Weld. Join. 2013, 18, 25-31. [CrossRef]

71. Digiovanni, C.; Bag, S.; Mehling, C.; Choi, K.W.; Macwan, A.; Biro, E.; Zhou, Y.N. Reduction in liquid metal embrittlement cracking using weld current ramping. Weld. World 2019, 63, 1583-1591. [CrossRef]

72. Murugan, S.P.; Mahmud, K.; Ji, C.; Jo, I.; Park, Y.D. Critical design parameters of the electrode for liquid metal embrittlement cracking in resistance spot welding. Weld. World 2019, 63, 1613-1632. [CrossRef]

73. Barthelmie, J.; Schram, A.; Wesling, V. Liquid metal embrittlement in resistance spot welding and hot tensile tests of surface-refined TWIP steels. IOP Conf.: Mater. Sci. Eng. 2016, 118, 012002. [CrossRef]

74. Ashiri, R.; Haque, M.A.; Ji, C.W.; Shamanian, M.; Salimijazi, H.R.; Park, Y.D. Supercritical area and critical nugget diameter for liquid metal embrittlement of Zn-coated twining induced plasticity steels. Scr. Mater. 2015, 109, 6-10. [CrossRef]

75. Digiovanni, C.; He, L.; Pistek, U.; Goodwin, F.; Biro, E.; Zhou, Y.N. Role of spot weld electrode geometry on liquid metal embrittlement crack development. J. Manuf. Proc. 2020, 49, 1-9. [CrossRef]

76. Lee, K.J.; Kim, S.H.; Kwon, E.P.; Son, K.S. Friction stir welding of 900MPa grade TWIP steel. JWJ 2014, 32, 135-139.

77. Hwang, S.; Yoon, H.S.; Kim, D.C.; Kang, M.J.; Kim, J.D.; Kim, Y.M. Resistance spot weldability of low density lightweight steel according to electrode shape. JWJ 2017, 35, 52-57. [CrossRef]

78. Valera, J.; Miguel, V.; Martinez, A.; Naranjo, J.; Canas, M. Optimization of electrical parameters in resistance rpot welding of dissimilar joints of micro-alloyed steels TRIP sheets. Procedia Manuf. 2017, 13, 291. [CrossRef]

79. Stoloff, N.S.; Johnston, T.L. Crack propagation in a liquid metal environment. Acta Metall. 1963, 11, $251-256$. [CrossRef]

80. Glickman, E.E. Dissolution condensation mechanism of stress corrosion cracking in liquid metals: Driving force and crack kinetics. Metall. Mater. Trans. A 2011, 42, 250-266. [CrossRef]

81. Lynch, S.P. Environmentally assisted cracking: Overview of evidence for an adsorption-induced localised-slip process. Acta Metall. 1988, 36, 2639-2661. [CrossRef]

82. Dmukhovskays, G.; Popovich, V.V. A phenomenological model of embrittlement of metals under conditions of the adsorption action of liquid metal media. Sov. Mater. Sci. 1983, 18, 461-467. [CrossRef]

83. Nicholas, M.G.; Old, C.F. Liquid metal embrittlement. J. Mater. Sci. 1979, 14, 1-18. [CrossRef]

84. Gordon, P.; An, H.H. The mechanisms of crack initiation and crack propagation in metal-induced embrittlement of metals. Metall. Trans. 1982, 13, 457-472. [CrossRef]

85. Klinger, L.; Rabkin, E. Theory of the Kirkendall effect during grain boundary interdiffusion. Acta Mater. 2011, 59, 1389-1399. [CrossRef]

86. Shunk, F.A.; Warke, W.R. Specificity as an aspect of liquid metal embrittlement. Scr. Metall. 1974, 8, 519-526. [CrossRef]

87. Ling, Z.; Wang, M.; Kong, L. Liquid Metal Embrittlement of Galvanized Steels During Industrial Processing: A Review. In Transactions on Intelligent Welding Manufacturing; Chen, S., Zhang, Y., Feng, Z., Eds.; Springer: Singapore, 2018; p. 29.

88. Frappier, R.; Paillard, P.; Gall, R.L.; Dupuy, T. Embrittlement of steels by liquid zinc: Crack propagation after grain boundary wetting. Adv. Mater. Res. 2014, 922, 161-166. [CrossRef]

89. Glickman, E.E. grain boundary grooving accelerated by local plasticity as a possible mechanism of liquid metal embrittlement. Interf. Sci. 2003, 11, 451-459. [CrossRef]

90. Joseph, B.; Picat, M.; Barbier, F. Liquid metal embrittlement: A state-of-the-art appraisal. Eur. Phys. J. Appl. Phys. 1999, 5, 19-31. [CrossRef] 
91. Ratanaphan, S.; Sarochawikasit, R.; Kumanuvong, N.; Hayakawa, S.; Beladi, H.; Rohrer, G.S.; Okita, T. Atomistic simulations of grain boundary energies in austenitic steel. J. Mater. Sci. 2019, 54, 5570-5583. [CrossRef]

92. Wang, J.; Madsen, G.K.H.; Drautz, R. Grain boundaries in bcc-Fe: A density-functional theory and tight-binding study. Model. Simul. Mater Sci. Eng. 2018, 26, 025008. [CrossRef]

93. Yu, J.; Yun, S.; Rhee, S. Optimization of fuzzy controller for constant current of inverter DC resistance spot welding using genetic algorithm. JWJ 2010, 28, 99-105.

94. Kim, J.K.; Woo, I.S.; Jeong, B.; Lee, J.B. Resistance spot weldability of ferritic stainless steel and galvanized steel. JWJ 2007, 24, 39-43.

95. Popovich, V.V. Mechanisms of liquid-metal embrittlement. Fiz.-Khim. Mekh. Mater. 1979, 15, 11-20. [CrossRef]

96. Beal, C.; Kleber, X.; Fabregue, D.; Mohamed, B. Liquid zinc embrittlement of twinning-induced plasticity steel. Scr. Mater 2012, 66, 1030-1033. [CrossRef]

97. He, L.; Digiovanni, C.; Han, X.; Mehling, C.; Wintjes, E.; Biro, E.; Zhou, N.Y. Suppression of liquid metal embrittlement in resistance spot welding of TRIP steel. Sci. Technol. Weld. Join. 2019, 24, 579-586. [CrossRef]

98. Marder, A.R. The metallurgy of zinc-coated steel. Prog. Mater. Sci. 2000, 45, 191-271. [CrossRef]

99. Kim, S.H.; Lee, J.H. Analysis of residual stresses for the multipass welds of 316L stainless steel pipe by neutron diffraction method. JWJ 2003, 21, 64-70.

100. Kang, H.S.; Cho, L.; Lee, C.; Cooman, B.C.D. Zn penetration in liquid metal embrittled TWIP Steel. Metall. Mater. Trans. A 2016, 47, 2885-2905. [CrossRef]

101. DiGiovanni, C.; Biro, F.; Zhou, N.Y. Impact of liquid metal embrittlement cracks on resistance spot weld static strength. Sci. Technol. Weld. Join. 2019, 24, 218-224. [CrossRef]

102. Gaul, H.; Weber, G.; Rethmeier, M. Influence of HAZ cracks on fatigue resistance of resistance spot welded joints made of advanced high strength steels. Sci. Technol. Weld. Join. 2011, 16, 440-445. [CrossRef]

103. Lee, H.S.; Jo, M.C.; Sohn, S.S.; Kim, S.H.; Song, T.; Kim, S.K.; Kim, H.S.; Kim, N.J.; Lee, S. Microstructural evolution of liquid metal embrittlement in resistance-spot-welded galvanized TWinning-Induced Plasticity (TWIP) steel sheets. Mater. Charact. 2019, 147, 233-241. [CrossRef]

104. Sharma, A.; Roh, M.H.; Jung, D.H.; Jung, J.P. Effect of $\mathrm{ZrO}_{2}$ nanoparticles on the microstructure of Al-Si-Cu filler for low-temperature Al brazing applications. Metall. Mater. Trans. A 2016, 47, 510-521. [CrossRef]

105. Sharma, A.; Lim, D.U.; Jung, J.P. Microstructure and brazeability of SiC nanoparticles reinforced Al-9Si-20Cu produced by induction melting. Mater. Sci. Technol. 2016, 32, 773-779. [CrossRef] 